\title{
A mountain of millipedes VIII. The genus Aquattuor Frederiksen, 2013 revisited - a new species from the Udzungwa Mts, Tanzania, another from the Nguru Mts, and introduction of the first pair of male legs as a source of taxonomic characters (Diplopoda, Spirostreptida, Odontopygidae)
}

\author{
Henrik ENGHOFF \\ Natural History Museum of Denmark, University of Copenhagen, \\ Universitetsparken 15, DK-2100 København Ø, Denmark. \\ Email: henghoff@snm.ku.dk
}

urn:1sid:zoobank.org:author:FB09A817-000D-43C3-BCC4-2BC1E5373635

\begin{abstract}
A large, newly collected material of the genus Aquattuor from the Udzungwa Mts, Tanzania, has been studied. Two new species are described, viz., A. mollilobus sp. nov. from the Udzungwa Mts and A. nguruensis sp. nov. from the Nguru Mts, Tanzania. Aquattuor claudiahempae Enghoff \& Frederiksen, 2015, is recorded as new for the Udzungwa fauna. Characters from the first pair of male legs are illustrated for all Aquattuor species and are shown to be useful for species discrimination. A new gonopodal difference between A. submajor Enghoff, 2015 and A. udzungwensis Enghoff, 2015 is described and illustrated. Intrageneric relationships and distribution patterns are discussed. A distribution map and a key to all Aquattuor species are presented.
\end{abstract}

Keywords. Eastern Arc, taxonomy, new species, identification key.

Enghoff H. 2020. A mountain of millipedes VIII. The genus Aquattuor Frederiksen, 2013 revisited - a new species from the Udzungwa Mts, Tanzania, another from the Nguru Mts and introduction of the first pair of male legs as a source of taxonomic characters (Diplopoda, Spirostreptida, Odontopygidae). European Journal of Taxonomy 626: $1-32$. https://doi.org/10.5852/ejt.2020.626

\section{Introduction}

The genus Aquattuor was described by Frederiksen (2013) for a new species from the East Usambaras in the Eastern Arc Mts of Tanzania. Enghoff \& Frederiksen (2015) reviewed the genus and added five new species from the Udzungwa Mts and one new species from Mt Kilimanjaro. Still another species, A. fasciatus (Attems, 1896), was re-allocated into Aquattuor by Enghoff(2016b). The genus thus currently includes eight species. Subsequently, a very large collection of Aquattuor spp. from the Udzungwa Mts has become available. The study of this material has clarified some problems of species delimitation; also, an additional new species from the Udzungwa Mts is described here. Additionally, a male from the Nguru Mts is here described as the tenth species of Aquattuor; this is probably conspecific with the female mentioned as "Aquattuor sp." in Enghoff \& Frederiksen (2015: 21). During the examination of 
the new material, several characters of the first pair of male legs have been found to exhibit significant inter-specific variation, see below.

The present contribution is the eighth in a series of papers devoted to the millipede fauna of the Udzungwa Mts Numbers 1-6 in the series (Enghoff 2014, 2016a, 2016b, 2016c, 2018a; Enghoff \& Frederiksen 2015) deal with Odontopygidae Attems, 1909, like the present one, while number 7 (Enghoff 2018b) is devoted to a genus of the family Paradoxosomatidae Daday, 1889.

In adult males of Odontopygidae the first pair of legs is modified; notably, the prefemur is enlarged and carries a large lobe on its anterior side. Similar lobes also occur in the related family Spirostreptidae Brandt, 1833 where details of their structure have been recognized as sometimes furnishing useful taxonomic characters (Krabbe 1979, 1982). In the Odontopygidae, however, variations in the first pair of male legs have not been explored, although several authors have described modification of these legs in certain species; see Mauriès (1997) who examined about 80 odontopygid species, found prefemoral lobes in them all, but did not describe the variation. The published drawings, however, suggest some interspecific variation, and this has been corroborated by a preliminary examination of several odontopygid species, not the least in the genus under consideration here. Therefore, characters from the first pair of legs are here described for all species of Aquattuor.

\section{Material and methods}

The vast majority of material comes from the zoological collections of the Natural History Museum of Denmark, University of Copenhagen (NHMD, formerly ZMUC). Almost all specimens were collected in pitfall traps by Jagoba Malumbres-Olarte. The holotype of the new species from the Nguru Mts derives from the Virginia Museum of Natural History (VMNH), where the very large collection of Tanzanian millipedes accumulated by Richard L. Hoffman (1927-2012) is housed.

Fig. 1 shows the collecting sites for Aquattuor spp. in the Udzungwa (sometimes spelled Uzungwa) Mts.

A total of 364 male specimens were examined, of which 305 belonged to one species, A. udzungwensis Enghoff, 2015. Some females have tentatively been referred to a species although in odontopygids, particularly in Aquattuor, only adult males can be identified to species level with any degree of certainty. All samples are kept in 70\% alcohol.

Specimens were stored and examined in $70 \%$ ethanol under a stereo microscope. Specimens for scanning electron microscopy (SEM) were cleaned with ultrasound, transferred to $96 \%$ ethanol, then to acetone, air-dried, mounted on aluminium stubs or on triangles of flexible aluminium tape, in turn mounted on stubs, coated with platinum/palladium and studied in a JEOL JSM-6335F scanning electron microscope. Images were processed in Photoshop (in some cases this included stacking of multiple images) and plates were composed in Microsoft Publisher.

The diagnoses and descriptions, including the measurements, apply to adult males, unless otherwise specified. Terminology and abbreviations as far as possible follow Enghoff \& Frederiksen (2015).

\section{Abbreviations for morphological terms used in descriptions and illustrations}

$\begin{aligned} b t l & =\text { basal telomeral lamella } \\ d p l & =\text { distal prefemoral lobe } \\ l i & =\text { lateral incision } \\ m b l & =\text { meso-basal lobe of palette } \\ m i & =\text { mesal incision } \\ m p l & =\text { meso-posterior telomeral lamella }\end{aligned}$




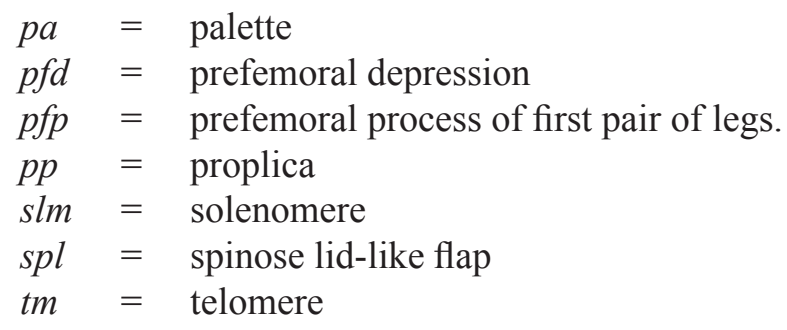

\section{Other abbreviations used in the text}

a.s.l. $\quad=$ above sea level

$\mathrm{FR}=$ Forest Reserve

Mts $=$ Mountains

$\mathrm{HMNH}=$ Hungarian Museum of Natural History, Budapest, Hungary

NHMD $=$ Natural History Museum of Denmark, Copenhagen, Denmark

$\mathrm{VMNH}=$ Virginia Museum of Natural History, Martinsville, VA, USA

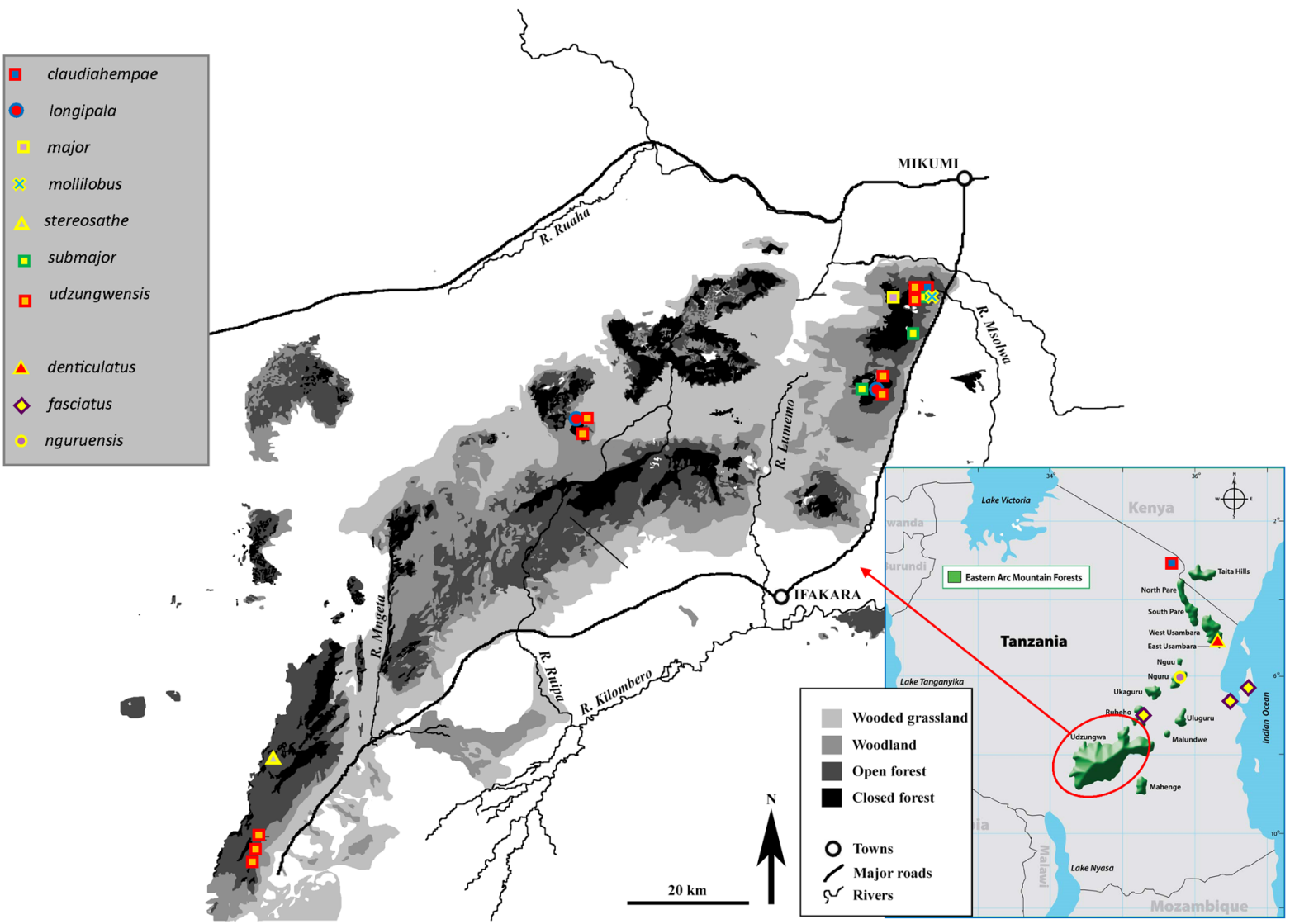

Fig. 1. Collecting sites for Aquattuor spp. in the Udzungwa Mts. Based on Marshall et al. (2010: fig. 1); inset by permission of the Eastern Arc Mountains Conservation Endowment Fund. 


\title{
Results
}

\section{Taxonomy}

\author{
Class Diplopoda de Blainville in Gervais, 1844 \\ Order Spirostreptida Brandt, 1833 \\ Family Odontopygidae Attems, 1909 \\ Subfamily Archepyginae Manfredi, 1939 \\ Tribe Prionopetalini Hoffman, 1991
}

Genus Aquattuor Frederiksen, 2013

Diagnosis (modified after Enghoff \& Frederiksen 2015)

Differs from all other Odontopygidae by the structure of the limbus, which consists of large, rectangular, easily detachable flaps. Gonopods of the Prionopetalini type, i.e., basomere of telopodite with a torsate flexible zone followed by a posttorsal narrowing; solenomere elongated. Gonopodal proplica apically expanded into a distal palette; metaplica with an oblique flange; solenomere simple, thin and whip-like; telomere terminating in a long, curved, gutter-like to tubular part.

\section{Descriptive notes}

For characters not mentioned here, see Enghoff \& Frederiksen (2015).

Mandibular stipes (Fig. 2): in males, but not in females with a disto-ventral expansion.

First pair of male legs: in the genus Aquattuor the first pair of legs is remarkably diverse. Figs 3-7 illustrate the first pair of legs in all known species of the genus, with a focus on the prefemur. In all of them, the prefemur carries a more or less finger-shaped process $(p f p)$ which projects orad from the
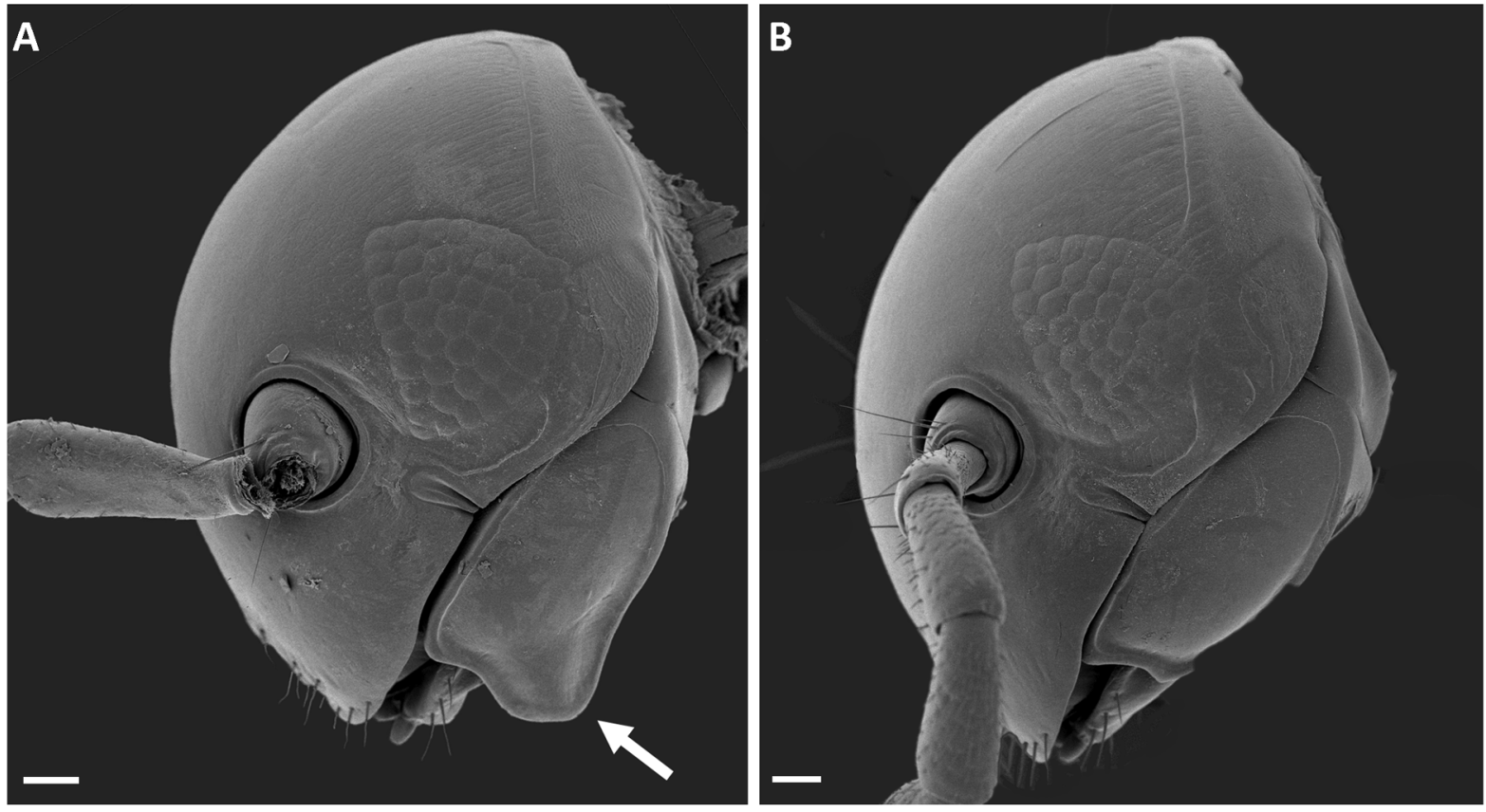

Fig. 2. Aquattuor udzungwensis Enghoff, 2015, specimens from Chita, heads, lateral view. A. Male (NHMD 621667). B. Female (NHMD 621667). Scale bars $=0.1 \mathrm{~mm}$. The arrow points at the distoventral stipital expansion lobe in the male. 
anterior surface of the prefemur (Figs 3-7). The distal (ventral) surface of the process is smooth, the basal (dorsal) surface is more or less scaly-rugose. The shape of the process varies from slender fingershaped to relatively broad/triangular, and in one species (A. nguruensis sp. nov.) there is a clearly delimited depression ( $p f d$ ) on the distal surface of the process (Fig. 4A-C). In A. major Enghoff, 2015, A. longipala Enghoff, 2015 and A. mollilobus sp. nov. there is in addition a second, more distal, more irregularly shaped prefemoral lobe ( $d p l$, Figs 5-6).

Another type of variation is seen in the setation of the telopodites of the first pair of legs (Fig. 8). Here, A. mollilobus sp. nov. (Fig. 8C) stands out by having very short setae on all podomeres. Aquattuor major and $A$. longipala have long setae on the tarsus, but very short ones on the femur (Fig. 8B). The remaining species have long setae (same length as on the following leg-pairs) on all podomeres (Fig. 8A). These differences in setation do not seem to reflect the setation of normal walking legs.

In one species (A. udzungwensis), the podomeres distal to the prefemur of the first leg pair seem to be invariably missing (several specimens examined) (Fig. 7D-E).

Adhesive pads on walking legs are absent.

Included species (alphabetically)

Aquattuor claudiahempae Enghoff \& Frederiksen, 2015

A. denticulatus Frederiksen, 2013 (type species)

A. fasciatus (Attems, 1896)

A. longipala Enghoff, 2015

A. major Enghoff, 2015

A. mollilobus sp. nov.

A. nguruensis sp. nov.

A. stereosathe Enghoff, 2015

A. submajor Enghoff, 2015

A. udzungwensis Enghoff, 2015

Aquattuor claudiahempae Enghoff \& Frederiksen, 2015

Figs 1, 3D-I, 9-10

Aquattuor claudiahempae Enghoff \& Frederiksen, 2015: 17.

\section{Diagnosis}

Diameter 1.41-1.58 mm, 50-53 podous rings (Fig. 9). Shares a short (as broad as long, or slightly longer) gonopodal palette with $A$. denticulatus, $A$. fasciatus, A. stereosathe, A. submajor, and $A$. udzungwensis. Differs from these species, except $A$. fasciatus, by the combination of fully developed telopodites on the first pair of male legs, the gonopodal telomere describing a ca $270^{\circ}$ curve, curving almost in one plane only, by lacking a spinose lid-like flap on the besal telomeral lamella, and by having a distinct mesobasal lobe of the gonopod palette. Very similar to, and perhaps not distinct from A. fasciatus, differs by being mostly smaller (male diameter $<1.7 \mathrm{~mm}$ ) and by having the prefemoral processes of the first pair of male legs more slender, finger-shaped.

Material studied (total: $25 \hat{\jmath} \widehat{\partial}, 29$ 웅)

TANZANIA • $1 \hat{\jmath}$, paratype; Kilimanjaro Region, Mt Kilimanjaro, Hai District; 03¹3'59.37" S, $37^{\circ} 16^{\prime} 09.28^{\prime \prime}$ E; $1345 \mathrm{~m}$ a.s.1.; 20 Nov. 2013; S.B. Frederiksen leg.; coffee plantation, Plot 2; NHMD 621638 • 24 ふึર, 29 우; Morogoro Region, Udzungwa Mts National Park, Kidatu, Plot 2; 
0741'14.9" S, 3656'24.7" E; 650 m a.s.1.; 24 Oct. 2014; J. Malumbres-Olarte leg.; pitfall trapping (summed catch from eight traps); NHMD 621639.

\section{Descriptive notes}

The specimens from Udzungwa Mts National Park very much resemble those from Mt Kilimanjaro (type locality of A. claudiahempae), in size (Fig. 9) as well as in gonopod structure (Fig. 10, cf. Enghoff \& Frederiksen 2015: fig. 10). In particular, the two samples agree in having the distal part of the telomere compressed, i.e., instead of forming a gutter, the lamella constituting the telomere is folded flat such that the inside of the gutter becomes invisible; the outside is strongly microspinose on one side and the free margin of the other side is characteristically wavy-spinose (Fig. 10D, Enghoff \& Frederiksen 2015: fig. 10d).
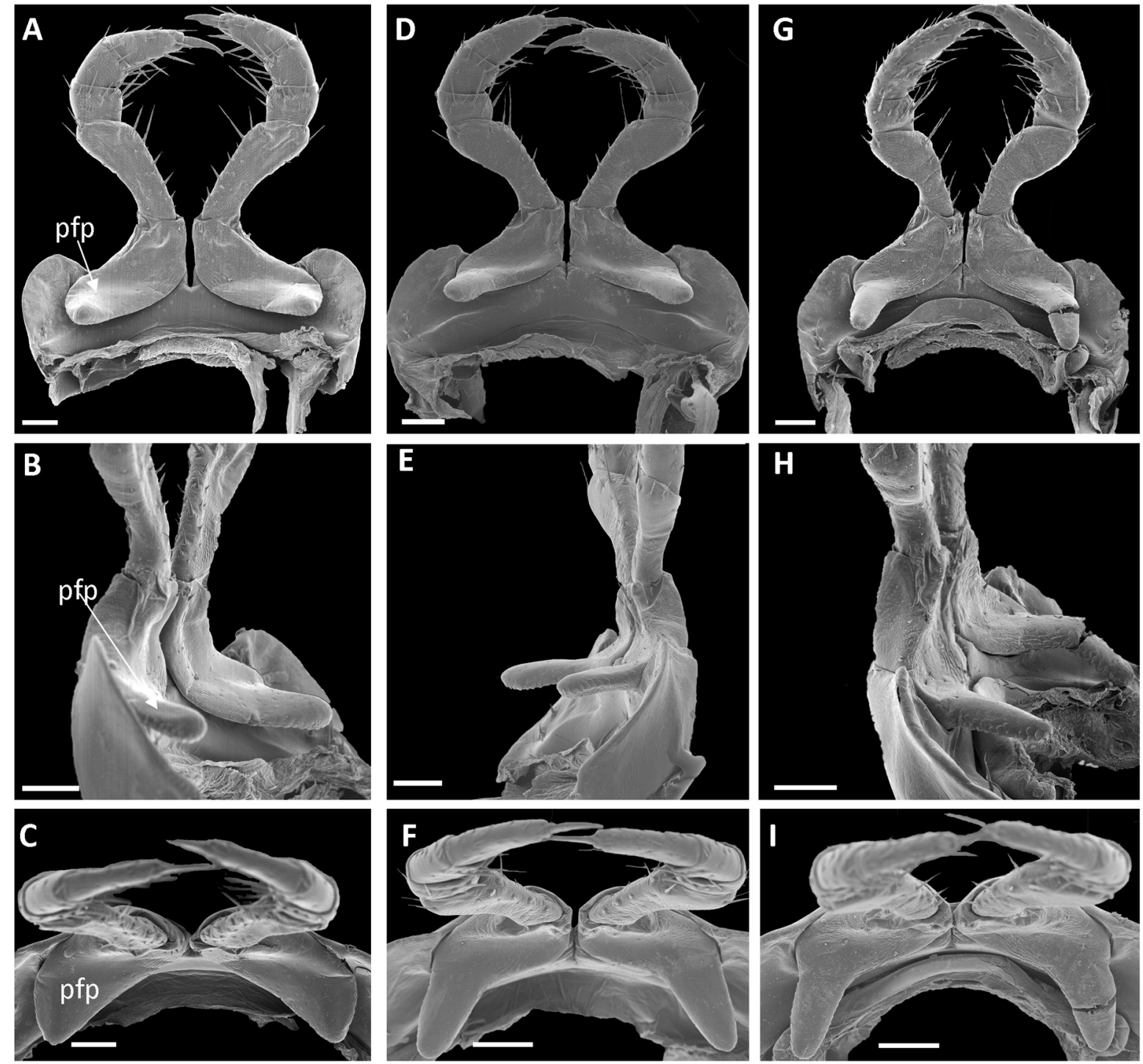

Fig. 3. Aquattuor spp., first pair of male legs. A-C. A. fasciatus (Attems, 1896), non-type male from Zanzibar (NHMD 621641). D-F. A. claudiahempae Enghoff \& Frederiksen, 2015, paratype from Kilimanjaro (NHMD 621638). G-I. A. claudiahempae, specimen from Udzungwa Mts (NHMD 621639). A, D, G. Anterior view. B, E, H. Sublateral view. C, F, I. Ventral view. Abbreviation: $p f p=$ prefemoral process. Scale bars $=0.1 \mathrm{~mm}$. 

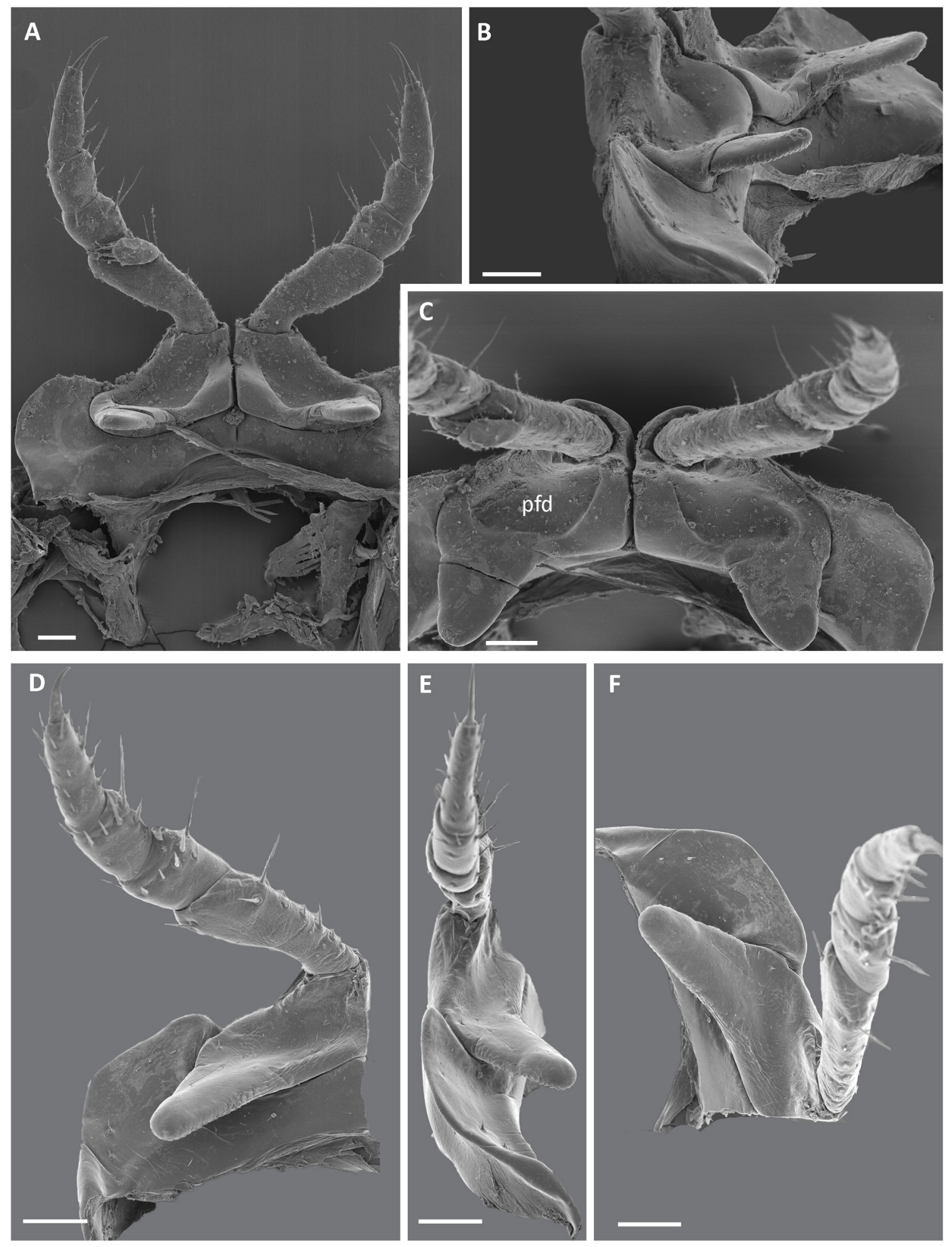

Fig. 4. A-C. Aquattuor nguruensis sp. nov., holotype, $\widehat{\partial}$ (VMNH110617), first pair of legs. Notice mite larva ("hypopus") on left femur. D-F. A. denticulatus Frederiksen, 2013, paratype, $\widehat{~}$ (NHMD 621640), left leg of first pair. A, D. Anterior view. B, E. Sublateral view. C, F. Sub-ventral view. Abbreviation: $p f d=$ prefemoral depression. Scale bars $=0.1 \mathrm{~mm}$. 

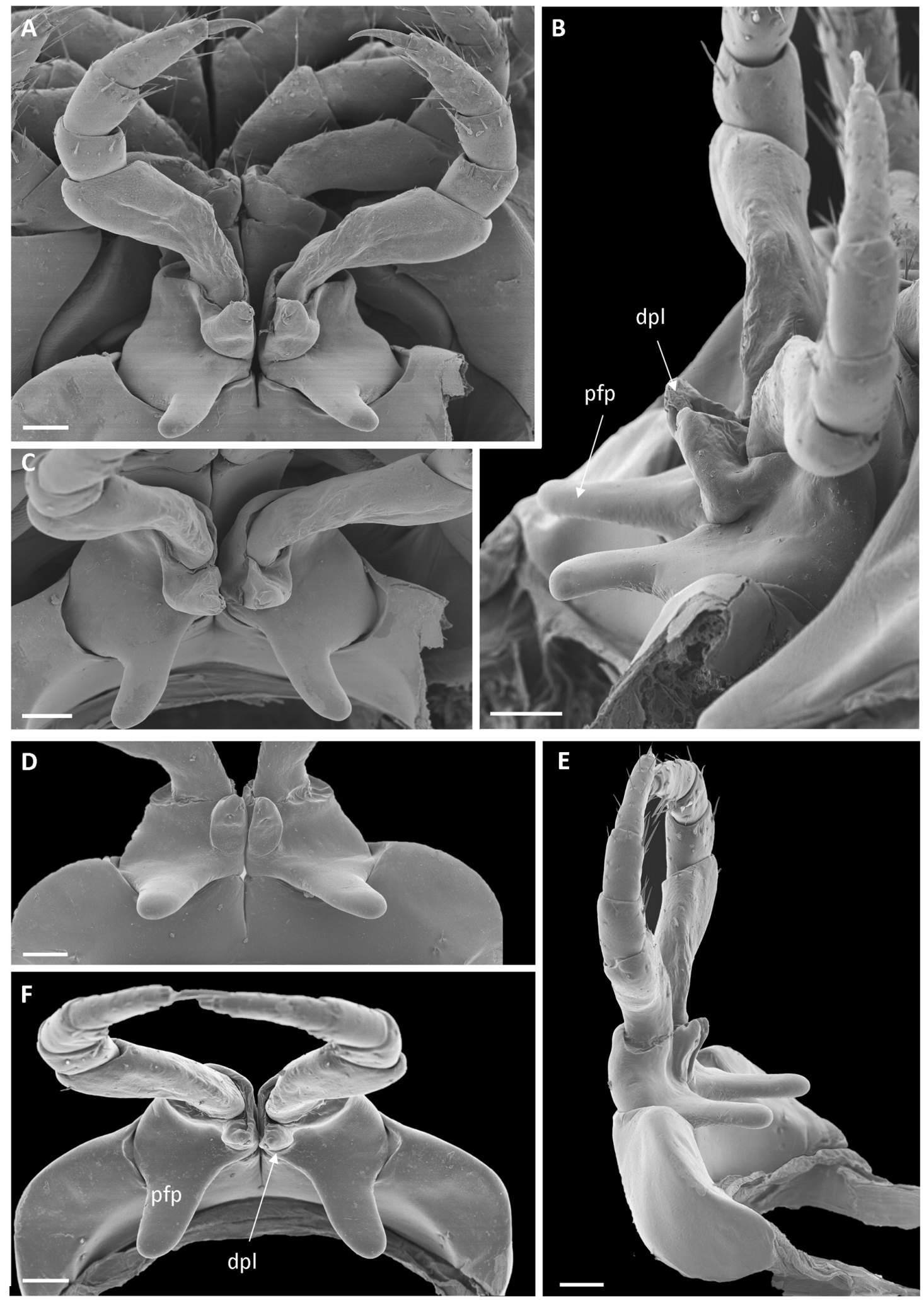

Fig. 5. Aquattuor spp., first pair of male legs. A-C. A. major Enghoff, 2015, paratype, $\widehat{\partial}$ (NHMD 621644), first pair of legs in situ. D-F. A. longipala Enghoff, 2015, male from Udzungwa Mts National Park, Mito Mitatu (NHMD 621642). A, D. Anterior view. B, E. Sublateral view. C, F. Sub-ventral view. Abbreviations: $d p l=$ distal prefemoral lobe; $p f p=$ prefemoral process. Scale bars $=0.1 \mathrm{~mm}$. 

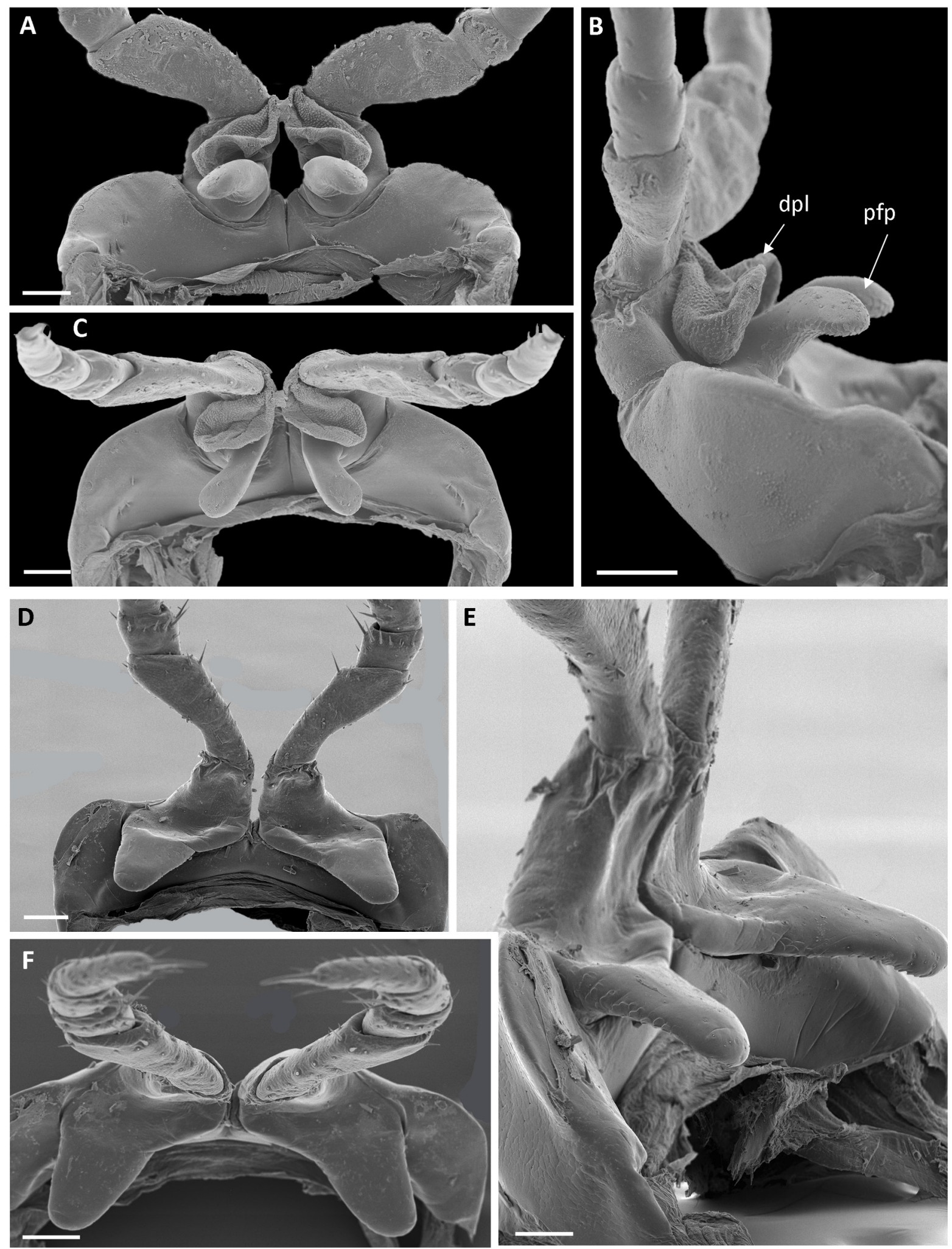

Fig. 6. Aquattuor spp., first pair of male legs. A-C. A. mollilobus sp. nov., paratype, § (NHMD 621647). D-F. A. stereosathe Enghoff, 2015, paratype, đิ (NHMD 621650). A, D. Anterior view. B, E. (Sub)lateral view. C, F. (Sub)-ventral view. Abbreviations: $d p l=$ distal prefemoral lobe; $p f p=$ prefemoral process. Scale bars $=0.1 \mathrm{~mm}$. 
First pair of male legs (Fig. 3D-I) each with a single, finger-shaped prefemoral process; prefemoral processes more slender than those of the otherwise very similar A. fasciatus (Fig. 3A-C); setae of telopodite distal to prefemur similar in length to those of normal walking legs.

\section{Distribution}

Described from Mt Kilimanjaro (1169-1345 m a.s.l., in habitats disturbed by human activities; Enghoff \& Frederiksen 2015); now also known from one site at $650 \mathrm{~m}$ a.s.l. in the Udzungwa Mts (Fig. 1).

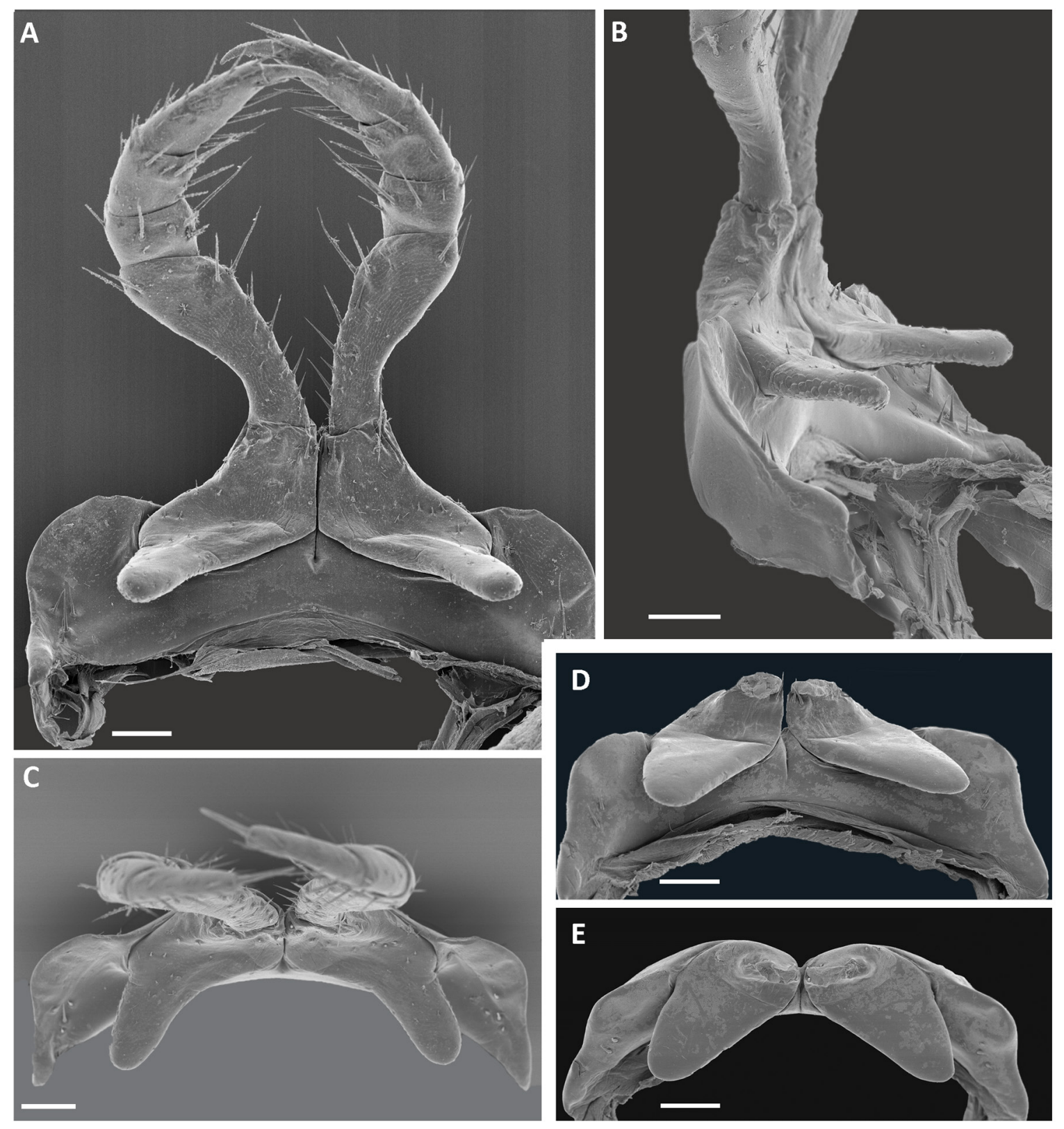

Fig. 7. Aquattuor spp., first pair of male legs. A-C. A. submajor Enghoff, 2015, paratype, $\widehat{0}$ (NHMD 621651). A. Anterior view. B. Sublateral view. C. Ventral view. D-E. A. udzungwensis Enghoff, 2015, male from Udzungwa Mts National Park, Kidatu (NHMD 621662). D. Anterior view. E. Ventral view. Scale bars $=0.1 \mathrm{~mm}$. 


\section{Remarks}

Enghoff (2016b) discussed A. fasciatus (Attems, 1896) (see below), emphasizing its great similarity with $A$. claudiahempae and suggesting that the latter might be a synonym of $A$. fasciatus. The similarity between both nominal species also extends to the compressed distal part of the telomere (Enghoff 2016b: fig. 7c, f). The only differences between the two seem to be size (cf. the identification key below, couplet 9) and the shape of the prefemoral process of the first pair of legs (Fig. 3). The new specimens of A. claudiahempae from Kidatu, Udzungwa Mts are of the same size as A. claudiahempae from Mt Kilimanjaro (Fig. 9), and their prefemoral processes strongly resemble those of Kilimanjaro specimens. Aquattuor claudiahempae and A. fasciatus are, for the time being, upheld as separate species.

Aquattuor denticulatus Frederiksen, 2013

Figs 1, 4D-F

Aquattuor denticulatus Frederiksen, 2013: 64.

\section{Diagnosis}

Diameter $1.58-1.77 \mathrm{~mm}, 50-52$ podous rings. Shares a short (as broad as long, or slightly longer) gonopodal palette with $A$. claudiahempae, A. fasciatus, A. stereosathe, A. submajor and A. udzungwensis. Differs from these species by having the subdistal part of the gonopodal telomere almost straight, parallel to the coxa, the telomere tip being bent abruptly laterad.
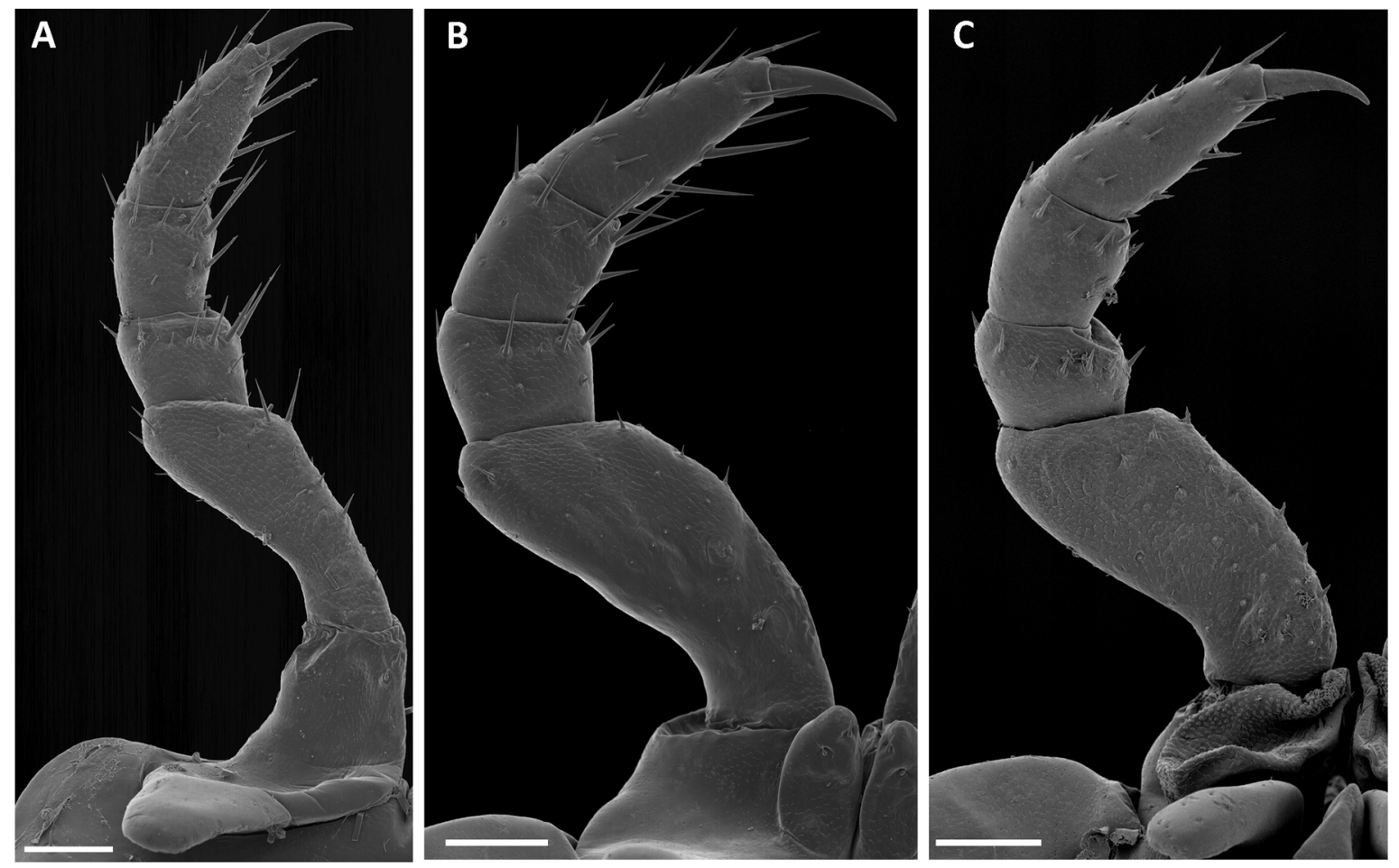

Fig. 8. Aquattuor spp., males, left leg of first pair. A. A. stereosathe Enghoff, 2015, paratype, $\widehat{\delta}$ (NHMD 621650): setae same length as in normal walking legs. B. A. longipala Enghoff, 2015, specimen from Udzungwa Mts National Park, Mito Mitatu (NHMD 621642): setae of femur shortened. C. A. mollilobus sp. nov., paratype, $\widehat{\partial}$ (NHMD 621646): all setae shortened. Scale bars $=0.1 \mathrm{~mm}$. 
Material studied (total: 1 う)

TANZANIA 1 1 , paratype; Tanga Region, Muheza District, East Usambara Mts, Amani, at Sigi River; 500 m a.s.l.; 7 Feb. 1977; H. Enghoff, O. Lomhodlt and O. Martin leg.; NHMD 621640 [=ZMUC 00020528].

\section{Descriptive notes}

First pair of male legs (Fig. 4D-F) each with a single, finger-shaped prefemoral process; setae of telopodite distal to prefemur similar in length to those of normal walking legs.

\section{Distribution}

Known only from the type locality, Tanga Region, Muheza District, E Usambara Mts, Amani. Altitudinal range: 500-1000 $\mathrm{m}$ a.s.1. (Frederiksen 2013).

\section{Aquattuor fasciatus (Attems, 1896)}

Figs $1,3 \mathrm{~A}-\mathrm{C}$

Odontopyge fasciata Attems, 1896: 40.

Prionopetalum fasciatum - Attems 1914: 210. — Brolemann 1920: 123. - Kraus 1960: 86. VandenSpiegel \& Pierrard 2009: 152. — Enghoff et al. 2016: 69.

Aquattuor aff. claudiahempae - Enghoff \& Frederiksen 2015: 19.

Aquattuor fasciatus - Enghoff 2016b: 14.

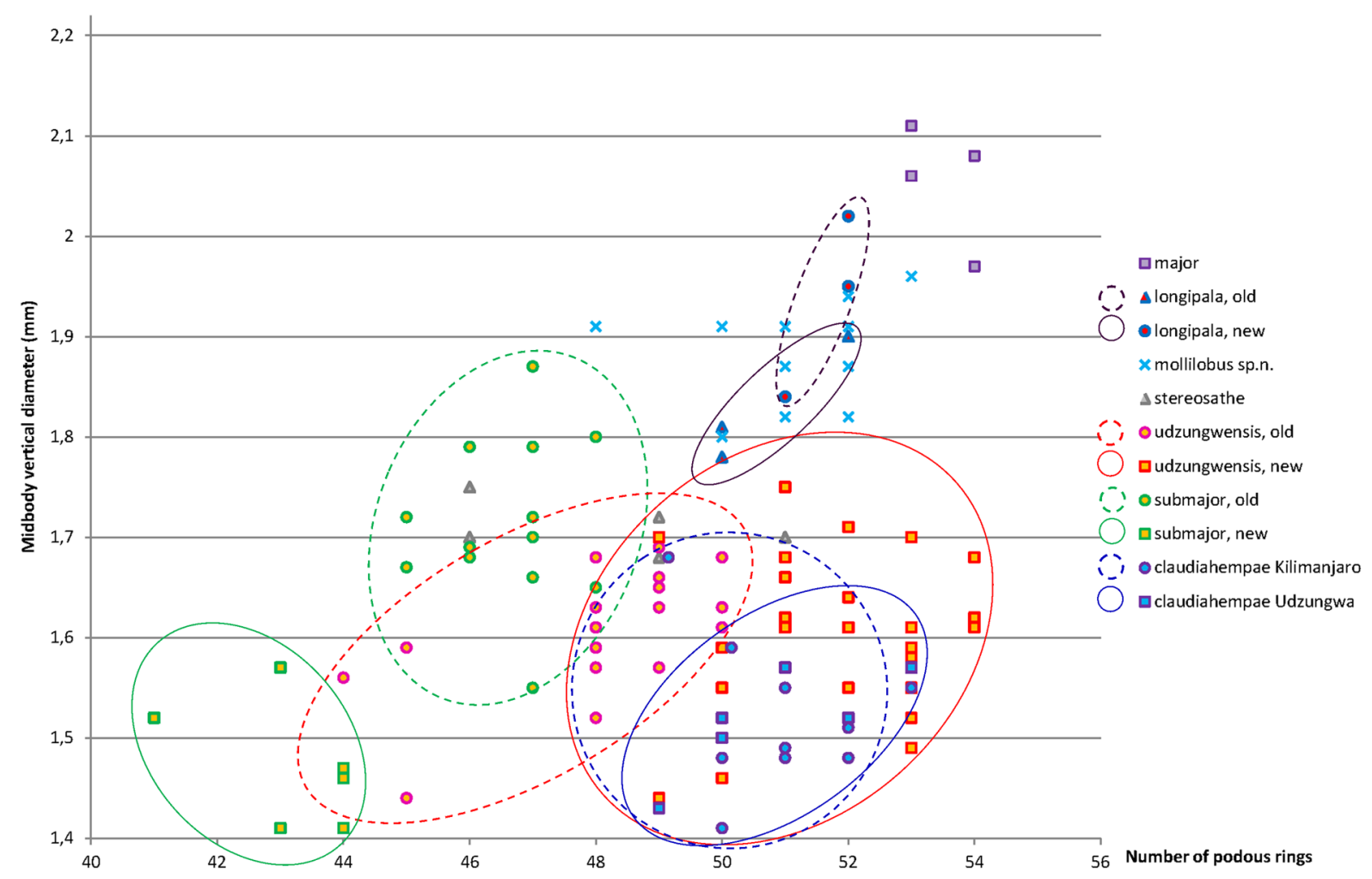

Fig. 9. Aquattuor spp. Body size (number of podous rings and midbody vertical diameter) in males of Aquattuor species from the Udzungwa Mts, and of A. claudiahempae Enghoff \& Frederiksen, 2015 from Mt Kilimanjaro. In case of (almost) coinciding values, symbols have been slightly displaced horizontally. 

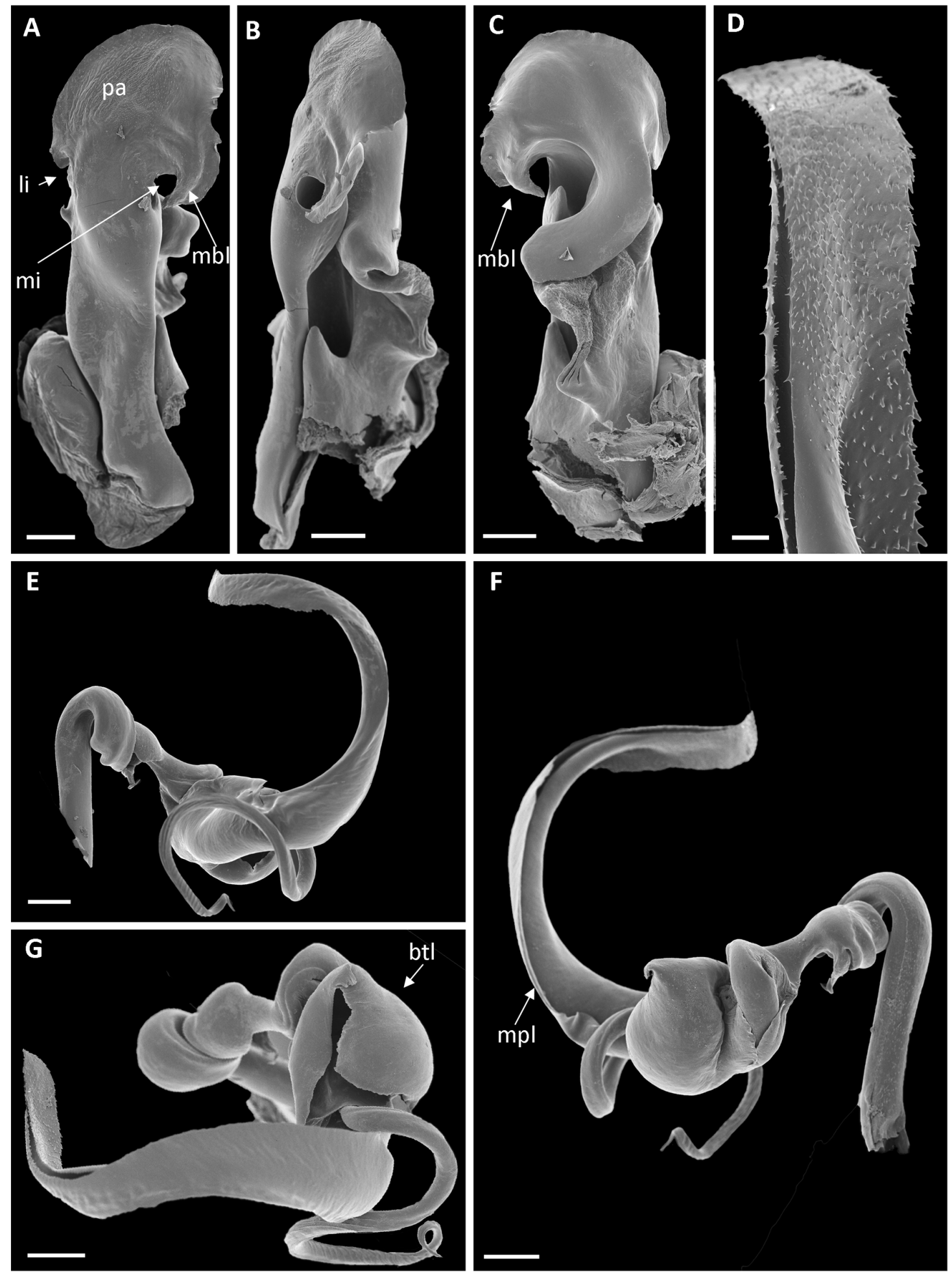

Fig. 10. Aquattuor claudiahempae Enghoff \& Frederiksen, 2015, male, specimen from the Udzungwa Mts (NHMD 621639), left gonopod. A-C. Coxa. A. Anterior view. B. Mesal view. C. Posterior view. D-G. Telopodite. D. Tip of telomere. E. Anterior view. F. Posterior view. G. Mesal view. Abbreviations: $b t l=$ basal telomeral lamella; $l i=$ lateral incision; $m b l=$ meso-basal lobe of palette $m i=$ mesal incision; $m p l=$ mesal-posterior telomeral lamella; $p a=$ palette. Scale bars: $\mathrm{A}-\mathrm{C}, \mathrm{E}-\mathrm{G}=0.1 \mathrm{~mm} ; \mathrm{D}=0.02 \mathrm{~mm}$. 


\section{Diagnosis}

Diameter 1.55-1.91 mm, 51-53 (55?) podous rings. Shares a short (as broad as long, or slightly longer) gonopodal palette with $A$. claudiahempae, A. fasciatus, A. stereosathe, A. submajor and A. udzungwensis. Differs from these species, except $A$. claudiahempae, by the combination of fully developed telopodites on the first pair of male legs, the gonopodal telomere describing a ca $270^{\circ}$ curve, curving almost in one plane only, by lacking a spinose lid-like flap on the basal telomeral lamella, and by having a distinct meso-basal lobe of the gonopod palette. Very similar to, and perhaps not distinct from A. claudiahempae, differs by being mostly larger (male diameter $>1.5 \mathrm{~mm}$ ) and by having the prefemoral processes of the first pair of male legs stouter, subtriangular.

Material studied (total: 1 Љ)

TANZANIA • 1 đ̊; Zanzibar, the sultan's palace; 16 Jun. 1979; M. Stoltze leg.; NHMD 621641.

\section{Descriptive notes}

First pair of male legs (Fig. 3A-C) each with a single, relatively stout, triangular prefemoral process; prefemoral processes stouter than those of the otherwise very similar A. claudiahempae; setae of telopodite distal to prefemur similar in length to those of normal walking legs.

See remarks under $A$. claudiahempae.

\section{Distribution}

Recorded from Zanzibar (type locality), Pwani Region, Bagamoyo Distr., Vula Mountain, Pongwe (VandenSpiegel \& Pierrard, 2009, as Prionopetalum fasciatum) and from Morogoro Region, Kilosa District, Rubeho Mts, $900 \mathrm{~m}$ a.s.l. (Enghoff \& Frederiksen 2015, as A. aff. claudiahempae).

Aquattuor longipala Enghoff, 2015

Figs 1, 5D-F, 8B, 9, 11

Aquattuor longipala Enghoff, in Enghoff \& Frederiksen, 2015: 12.

\section{Diagnosis}

Diameter 1.78-2.02 mm, 50-52 podous rings (Fig. 9). Differs from congeners, except A. longipala and $A$. major, by having the gonopodal palette considerably longer than broad, and by having a distal prefemoral lobe on the first pair of male legs, in addition to the normal prefemoral process. Differs from A. mollilobus sp. nov. by having distinct lateral and mesal incisions on the gonopod coxa and by having the tarsal setae of the first pair of male legs of normal length; differs from A. major in lacking a triangular tooth on the anterior margin of the gonopod telomere.

Material studied (total: $3 \hat{\jmath} \widehat{\partial}, 3$ 우, 3 juvs)

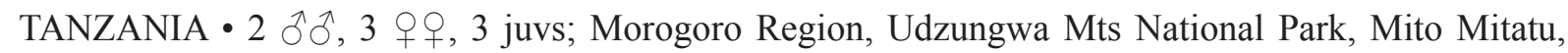
Plot 15; 0749'39.8" S, 3650'26.0" E; 1552 m a.s.1.; 27 Oct. 2014; J. Malumbres-Olarte leg.; pitfall trapping (summed catch from two traps); NHMD $621642 \cdot 1$ ते; Morogoro Region, Udzungwa Mts National Park, Mito Mitatu; 0750'14.3" S, 3650'46.8" E; 1207 m a.s.l.; 25 Nov. 2013; T. Pape and N. Scharff leg.; pitfall trapping; NHMD 621643.

\section{Descriptive notes}

The new specimens perfectly fit the original description of $A$. longipala, except that they are marginally larger (51-52 podous rings, diameter $1.84-2.02 \mathrm{~mm}$, vs 50-52 podous rings, diameter $1.78-1.90 \mathrm{~mm}$ for type specimens) (Fig. 9). 

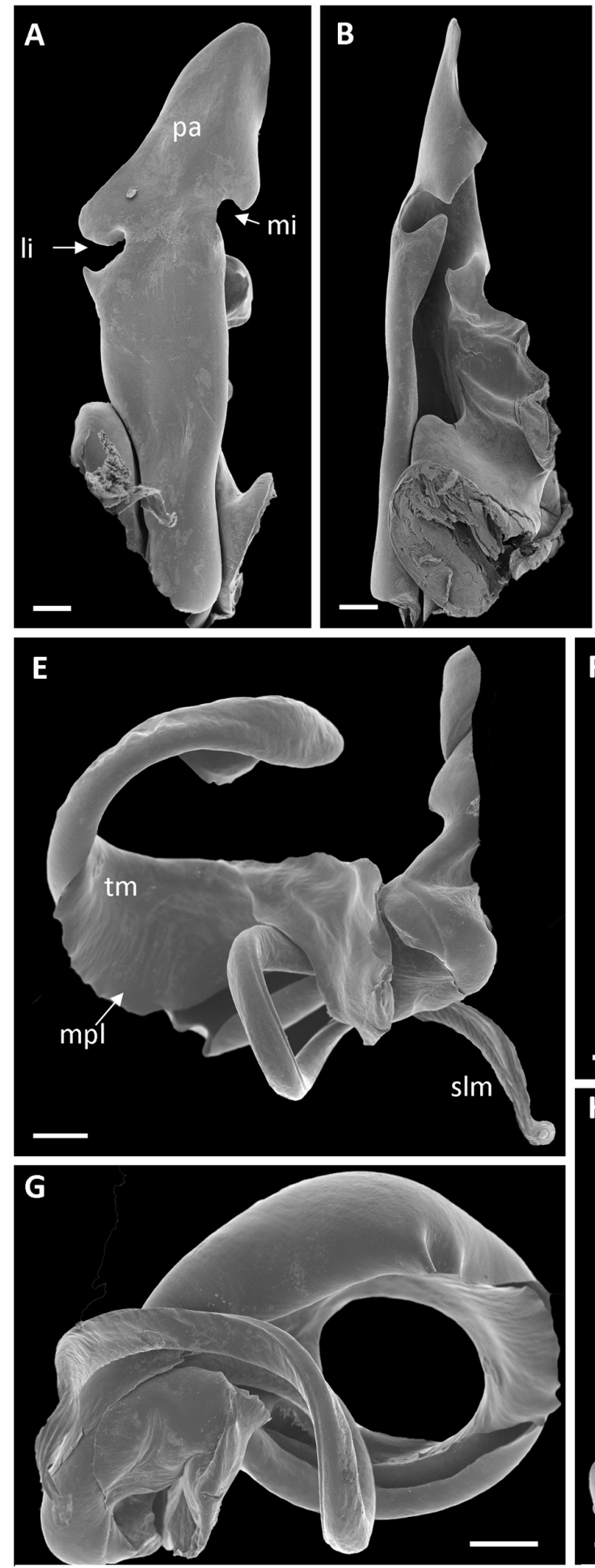
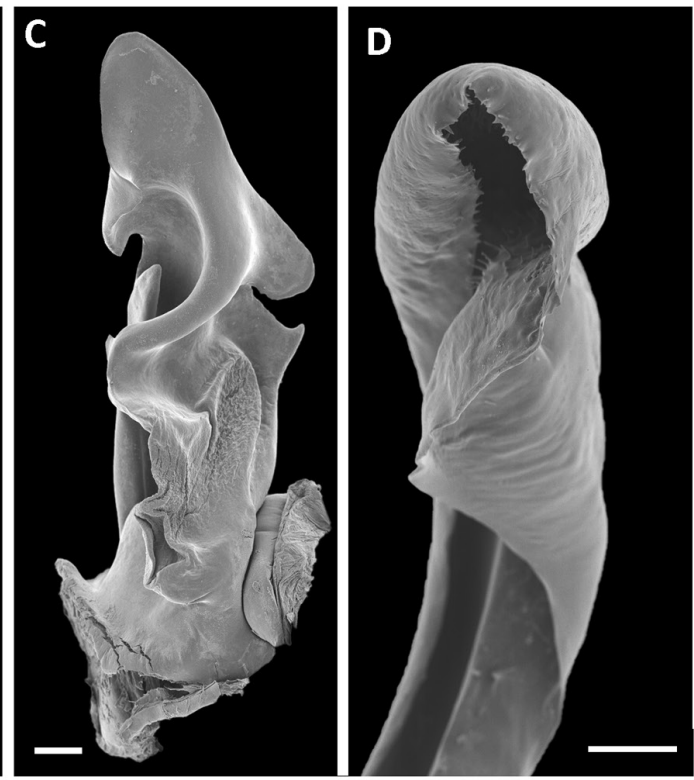

F
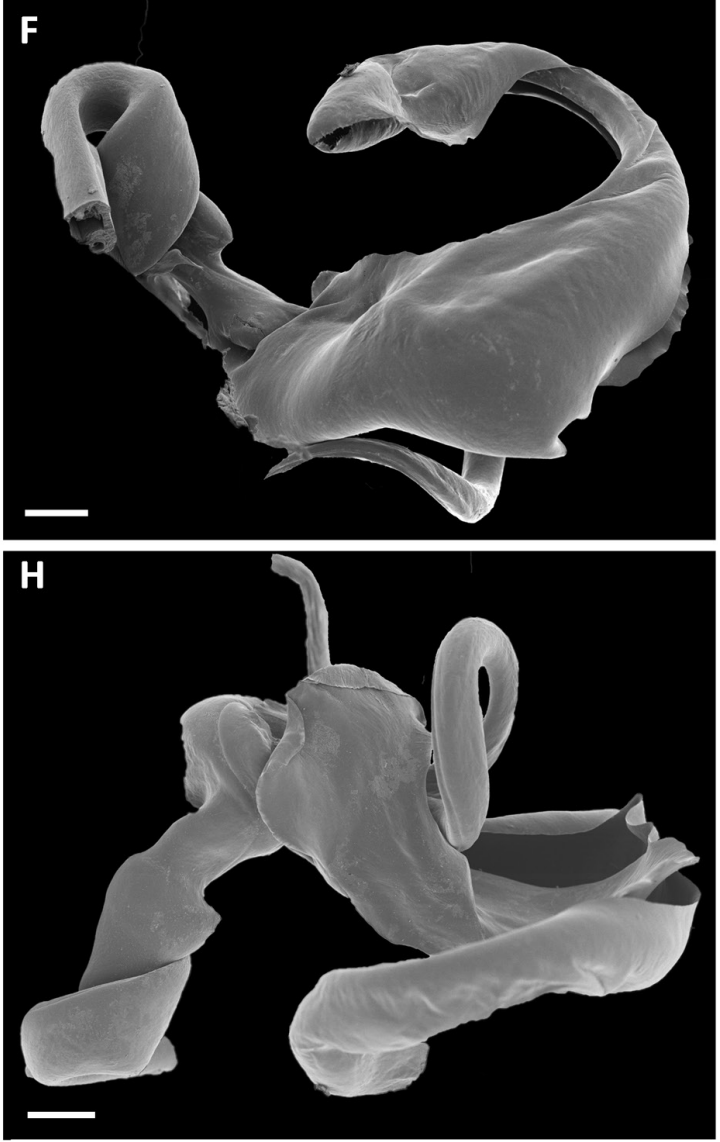

Fig. 11. Aquattuor longipala Enghoff, 2015, male, specimen from Udzungwa Mts National Park, Mito Mitatu (NHMD 621642), left gonopod. A-C. Coxa. A. Anterior view. B. Mesal view. C. Posterior view. D-H. Telopodite. D. Tip of telomere. E. Posterior view. F. Anterior view. G. Posterior-ventral view. H. Distal (ventral) view. Abbreviations: $l i=$ lateral incision; $m i=$ mesal incision; $m p l=$ mesal-posterior telomeral lamella; $p a=$ palette; $s l m=$ solenomere; $t m=$ telomere. Scale bars: A-C, E-H $=0.1 \mathrm{~mm}$; $\mathrm{D}=0.05 \mathrm{~mm}$. 
First pair of male legs (Fig. 5D-F) each with a single slender, finger-shaped prefemoral process ( $p f p$ ); in addition, each prefemur has a smaller, irregular lobe $(d p l)$ on the oral side of the distal margin; setae of femur much shorter than corresponding setae on normal walking legs (Fig. 8B).

Fig. 11 shows a gonopod of one of the newly collected specimens.

Aquattuor longipala is very similar to A. major (see Discussion).

\section{Distribution}

Known from two sites in the Udzungwa Mts, viz., West Kilombero FR and Mito Mitatu in Udzungwa Mts National Park (Fig. 1). Altitudinal range: 1207-1552 m a.s.1.

Aquattuor major Enghoff, 2015

Figs 1, 5A-C, 9

Aquattuor major Enghoff, in Enghoff \& Frederiksen, 2015: 10.

\section{Diagnosis}

Diameter 1.97-2.11 mm, 53-54 podous rings (Fig. 9). Differs from congeners, except A. longipala and A. mollilobus sp. nov., by having the gonopodal palette considerably longer than broad, and by having a distal prefemoral lobe on the first pair of male legs, in addition to the normal prefemoral process. Differs from A. longipala and A. mollilobus sp. nov. by having a triangular tooth on the anterior margin of the gonopod telomere, from A. mollilobus sp. nov. further by having distinct lateral and mesal incisions on the gonopod coxa and by having the tarsal setae of the first pair of male legs of normal length.

Material studied (total: 1 ふ)

TANZANIA 11 , paratype; Morogoro Region, Udzungwa Mts, Mwanihana FR, above Sanje; $1650 \mathrm{~m}$ a.s.l.; 18 Aug. 1982; M. Stoltze and N. Scharff leg.; pitfall trap; NHMD 621644.

\section{Descriptive notes}

First pair of male legs (Fig. 5A-C) each with a single, finger-shaped prefemoral process ( $p f p$ ); in addition each prefemur has a smaller, irregular lobe $(d p l)$ on the oral side of the distal margin; setae of femur much shorter than corresponding setae on normal walking legs, as in A. longipala (see Fig. 8B).

Aquattuor major is very similar to A. longipala (see Discussion).

\section{Distribution}

Known only from Mwanihana FR in the Udzungwa Mts. Altitudinal range: $1650-1850 \mathrm{~m}$ a.s.1.

Aquattuor mollilobus sp. nov. urn:1sid:zoobank.org:act:A453CBE6-5FF7-4327-9B45-FA0C6A9AE84F

Figs 1, 6A-C, 8C, 9, 12-13

\section{Diagnosis}

Diameter 1.80-1.96 mm, 48-53 podous rings (Fig. 9). Differs from congeners, except A. longipala and $A$. major, by having the gonopodal palette considerably longer than broad, and by having a distal prefemoral lobe on the first pair of male legs, in addition to the normal prefemoral process. Differs from A. longipala and A. major by having the lateral and mesal incisions of the gonopod coxa indistinct, and by having the tarsal setae of the first pair of male legs much shorter than tarsal setae of normal walking legs. 


\section{Etymology}

The name is an adjective meaning soft (Latin: mollis) lobe and refers to the distal modification of the first male prefemora.

Material studied (total: $21 \hat{\jmath}, 11 \stackrel{+}{\circ, 1}, 1$ juv.)

\section{Holotype}

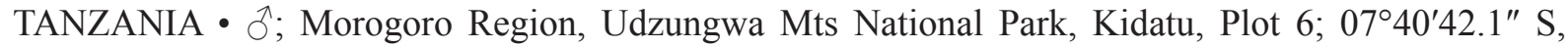
36 55'06.8" E; 1482 m a.s.1.; 21 Oct. 2014; J. Malumbres-Olarte leg.; pitfall trapping; NHMD 621645.
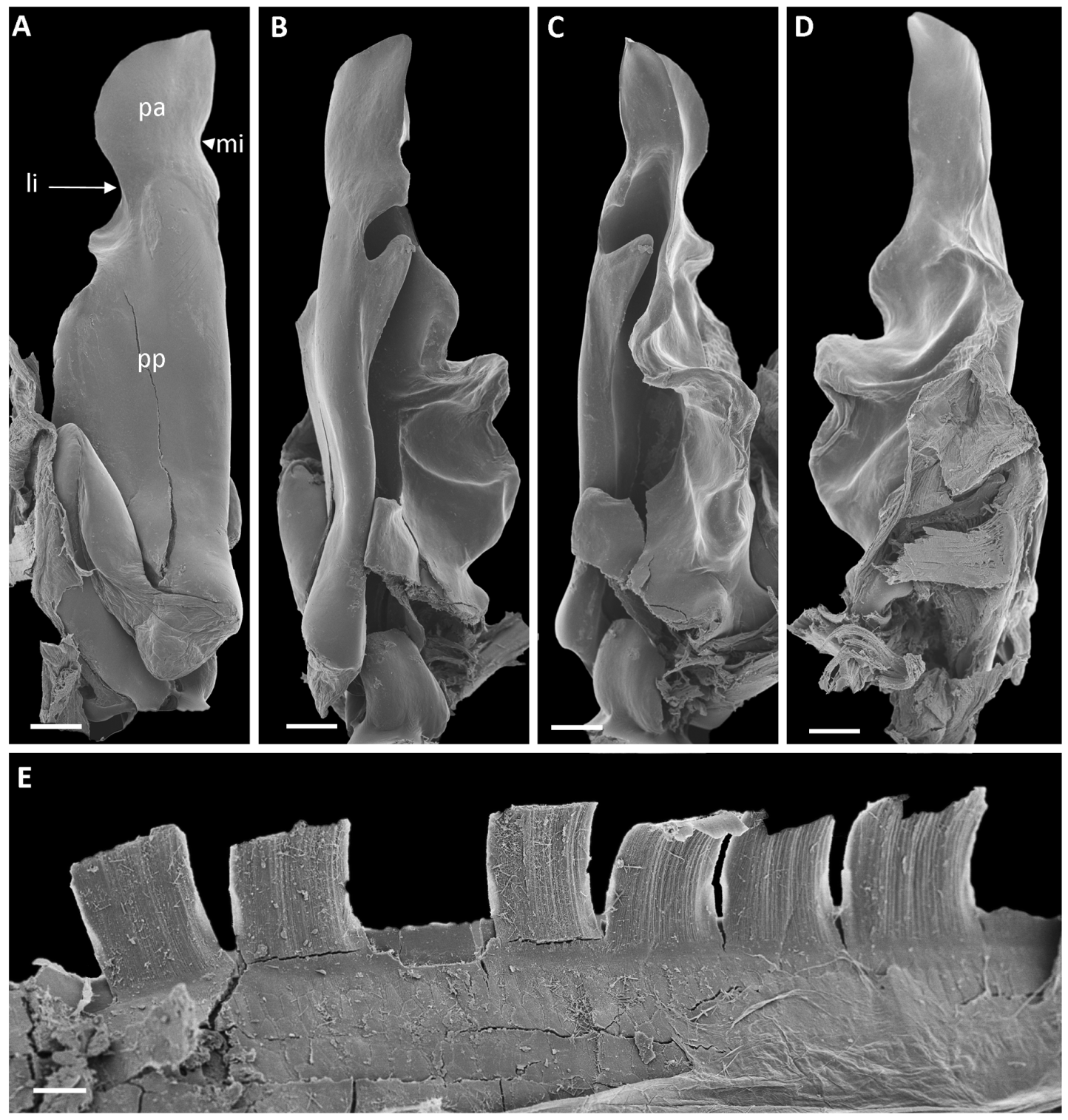

Fig. 12. Aquattuor mollilobus sp. nov., paratype, đ (NHMD 621648). A-D. Left gonopod coxa. A. Anterior view. B. Anterior-mesal view. C. Mesal view. D. Posterior-lateral view. E. Midbody dorsal limbus. Abbreviations: $l i=$ lateral incision; $m i=$ mesal incision; $p a=$ palette; $p p=$ proplica. Scale bars: A-D $=0.1 \mathrm{~mm} ; \mathrm{E}=0.02 \mathrm{~mm}$. 

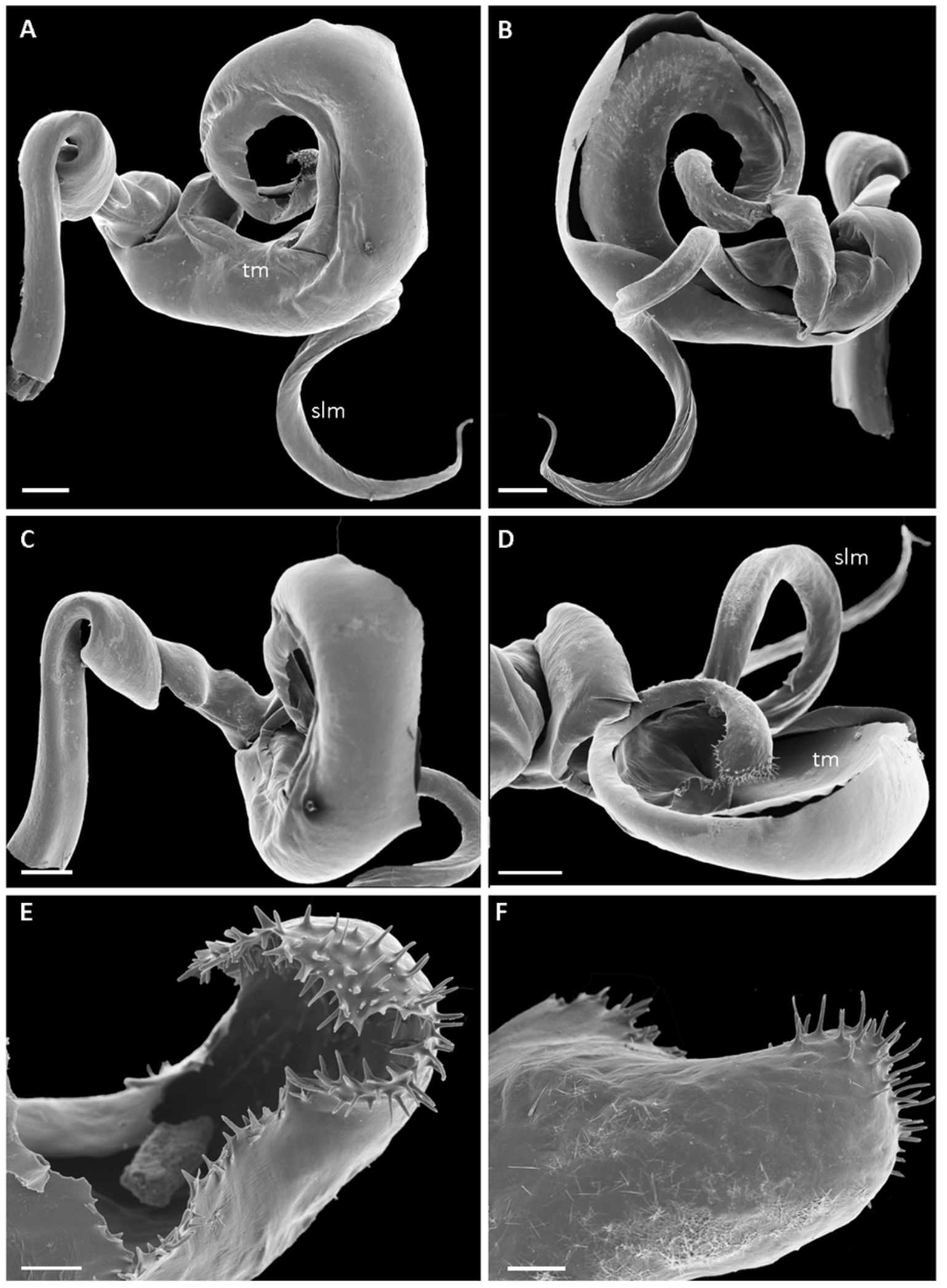

Fig. 13. Aquattuor mollilobus sp. nov., paratype, $\widehat{\jmath}$ (NHMD 621648). Left gonopod telopodite. A. Anterior view. B. Posterior view. C. Submesal view. D. Distal (ventral) view. E-F. Tip of telomere. Abbreviations: $s l m=$ solenomere; $t m=$ telomere. Scale bars: A-D $=0.1 \mathrm{~mm} ; \mathrm{E}-\mathrm{F}=0.02 \mathrm{~mm}$. 
ENGHOFF H., The millipede genus Aquattuor revisited

\section{Paratypes}

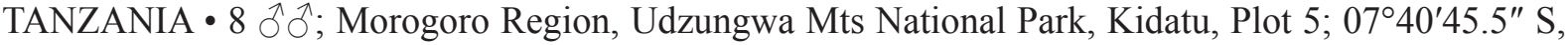
36 55'06.9" E; 1448 m a.s.1.; 21 Oct. 2014; J. Malumbres-Olarte leg.; pitfall trapping (summed catch

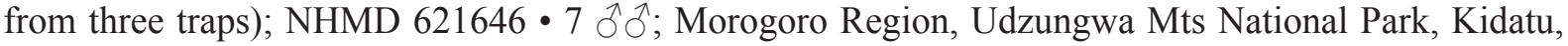
Plot 6; 07²0'42.1" S, 3655'06.8" E; 1482 m a.s.1.; 21 Oct. 2014; J. Malumbres-Olarte leg.; pitfall trapping (summed catch from six traps); NHMD 621647 • 5 ôं; Morogoro Region, Udzungwa Mts National Park, Kidatu, Plot 9; 07²4'06.2" S, 3655'06.8' E,1527 m a.s.1.; 23 Oct. 2014; J. MalumbresOlarte leg.; pitfall trapping (summed catch from three traps); NHMD 621648.

\section{Referred non-type material}

TANZANIA • 11 우, 1 juv.; same collection data as for paratypes (plots 5, 6, 9); NHMD.

Description (male)

Measurements. Body length $28-31 \mathrm{~mm}$; vertical diameter $1.82-1.91 \mathrm{~mm} ; 48-53$ podous rings, no apodous rings in front of telson.

Colour. Similar to that of $A$. claudiahempae (Enghoff \& Frederiksen 2015: fig. 1). A light mid-dorsal stripe present.

LimBus (Fig. 12E). With rectangular, detachable flaps, as typical of the genus.

First pair of MALE Legs (Figs 6A-C, 8C). Prefemoral processes ( $p f p$ ) of first pair of legs slender, fingershaped, slightly curved laterad; in addition an irregular, rugose lobe $(d p l)$ on oral-distal margin of prefemur; setae of all podomeres much shorter than femoral setae of normal walking legs.

GonOPOD COXA (Fig. 12A-D). In anterior or posterior view ca $3 \frac{1}{2} \times$ as long as broad. Margins of proplica $(p p)$ parallel in basal $\mathrm{ca}^{2} / 3$. Mesal $(\mathrm{mi})$ and lateral ( $\mathrm{li}$ ) incisions shallow and poorly developed; apical palette $(p a)$ narrower than basal part of proplica, lateral margin regularly rounded, mesal margin straight.

Gonopod telopodite (Fig. 13). Solenomere $(\mathrm{slm})$ thin, whiplike. Main part of telomere $(\mathrm{tm})$ a rather broad gutter describing a $270^{\circ}$ curve in almost one plane; tip of telomere broad rounded, densely beset with minute spicules on external surface.

In all other characters conforming to the general description of Aquattuor in Enghoff \& Frederiksen (2015).

\section{Distribution}

Known only from a single site in Udzungwa Mts National Park (Fig. 1). Altitudinal range: 1448-1527 m a.s.l.

Aquattuor nguruensis sp. nov.

urn:1sid:zoobank.org:act:B691ECD6-3E7E-4731-AD33-1DD9D39381DB

Figs $1,4 \mathrm{~A}-\mathrm{C}, 14-15$

Aquattuor sp. - Enghoff \& Frederiksen 2015: 21 (?).

\section{Diagnosis}

Diameter $2.0 \mathrm{~mm}$. Differs from congeners by lacking lateral and mesal incisions on the gonopod coxa and by having the telomere tip flattened and smooth. Differs from A. mollilobus sp. nov., in which the lateral and mesal incisions are indistinct, by lacking a distal prefemoral lobe on the first pair of male legs. 


\section{Etymology}

The name is an adjective referring to the type locality.

Material studied (total: $1 \hat{\jmath}, 2$ + )

\section{Holotype}

TANZANIA - 3 ; Morogoro Region and District, west side of Nguru Mountains, near Maskati mission, 20 km W of Turisani; 1900 m a.s.l.; unknown date; Jan Kielland leg.; moist evergreen forest; VMNH110617.

\section{Referred non-type material}

TANZANIA • 1 \%; same collection data as for holotype; VMNH110618 • 1 \% ; Nguru Mts, Mhonda Mission at Turiani; Oct. 1992; M. Andersen leg.; NHMD 621649.
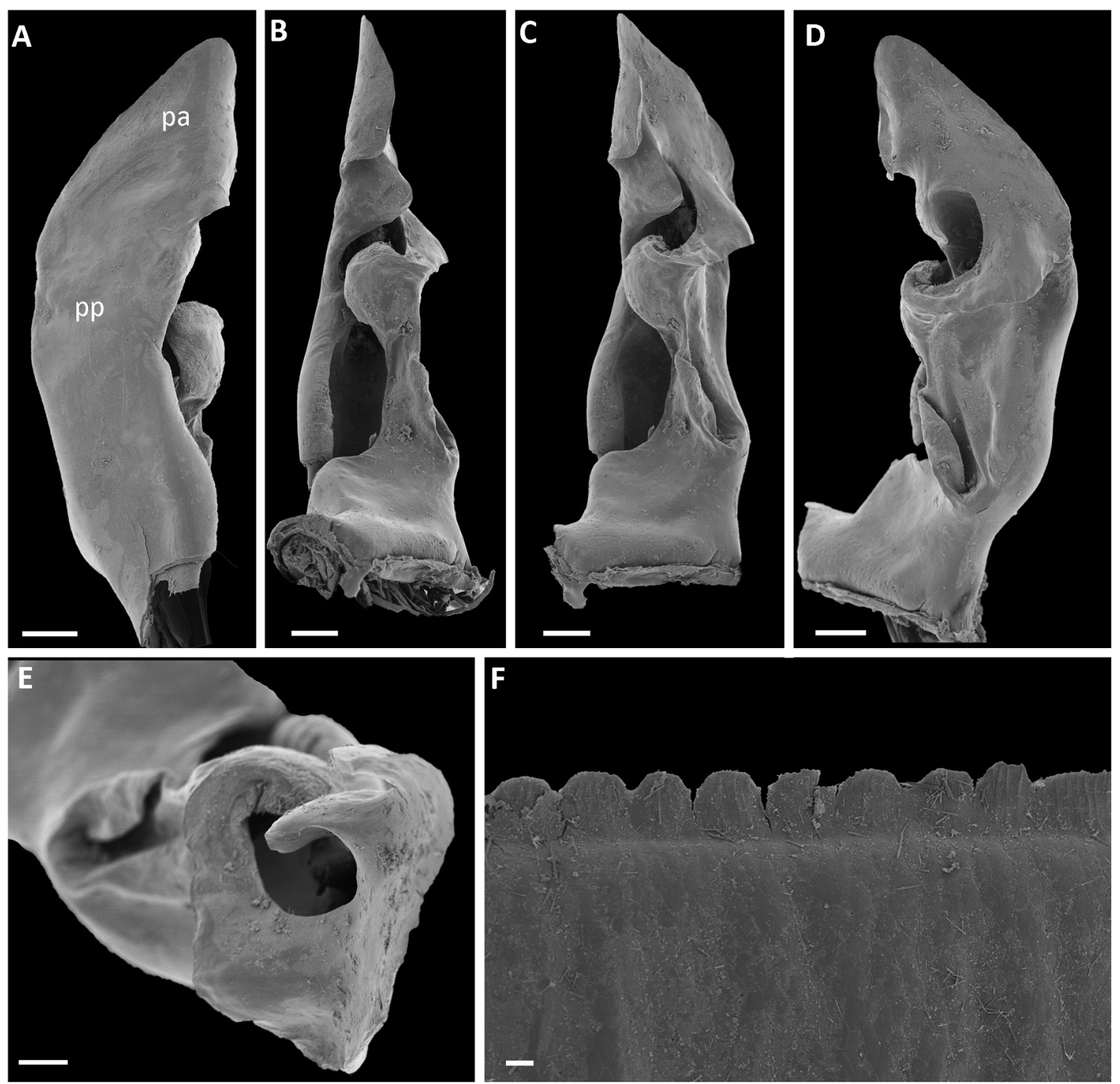

Fig. 14. Aquattuor nguruensis sp. nov., holotype, ô (VMNH110617). A-E. Left gonopod coxa. A. Anterior view. B. Mesal view. C. Meso-posterior view. D. Posterior view. E. Apical view. F. Midbody dorsal limbus. Abbreviations: $p a=$ palette; $p p=$ proplica. Scale bars: A-D $=0.1 \mathrm{~mm}$; $\mathrm{E}=0.05 \mathrm{~mm} ; \mathrm{F}=0.01 \mathrm{~mm}$. 


\section{Description (male)}

MEASUREMENTS. Vertical diameter $2.0 \mathrm{~mm}$; posterior part of body missing.

CoLour. Faded, but apparently similar to that of A. claudiahempae (Enghoff \& Frederiksen 2015: fig. 1). Traces of a light mid-dorsal stripe present.

LimBus (Fig. 14F). Quite worn, but still shows rectangular, detachable flaps as typical of the genus.
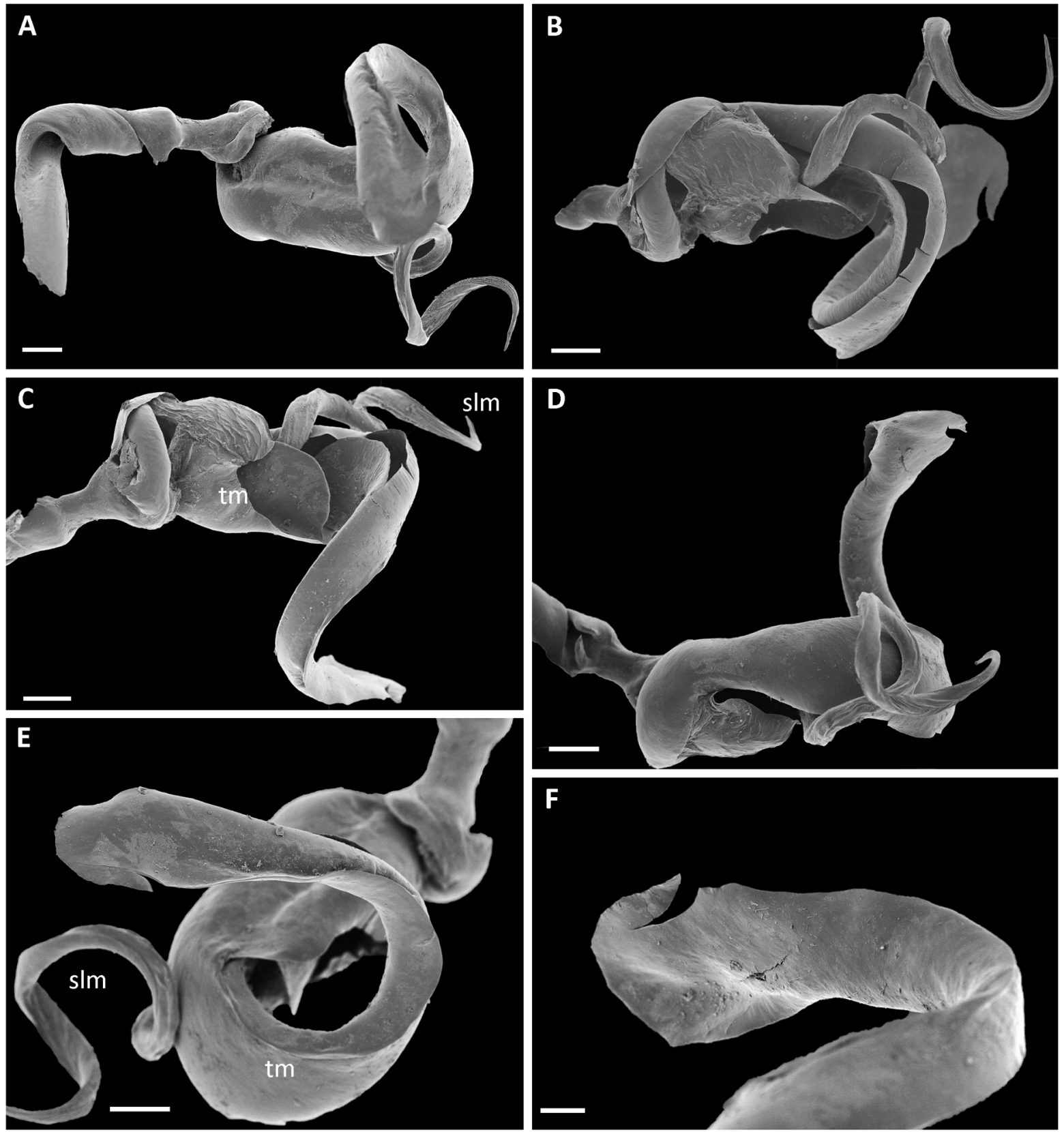

Fig. 15. Aquattuor nguruensis sp. nov., holotype, đ (VMNH110617), left gonopod telopodite. A. Anterior view. B. Posterior view. C. Distal (ventral) view. D. Basal (dorsal) view. E. Mesal view. F. Tip of telomere (damaged). Abbreviations: $s t m=$ solenomere; $t m=$ telomere. Scale bars: A-E $=$ $0.1 \mathrm{~mm} ; \mathrm{F}=0.05 \mathrm{~mm}$. 
First Pair of MALE Legs (Figs 4A-C). Prefemoral processes relatively stout, triangular; distal (ventral) surface of processes with a large, sharply delimited depression $(p f d)$; setae of telopodite distal to prefemur same length as setae of normal walking legs.

GoNOPOD COXA (Fig. 14). In anterior or posterior view ca $3 \times$ as long as broad. Margins of proplica subparallel, but lateral margin regularly convex, mesal margin correspondingly concave. No mesal and lateral incisions, apical palette $(p a)$ hence poorly delimited, triangular.

Gonopod telopodite (Fig. 15). Solenomere $(\mathrm{slm})$ thin, whip-like. Main part of telomere a rather broad gutter describing a $270^{\circ}$ curve in almost one plane; tip of telomere flattened, smooth.

In all other characters conforming to the general description of Aquattuor in Enghoff \& Frederiksen (2015).

\section{Distribution}

Known only from one, possibly two sites in the Nguru Mts. Altitude: 1900 m a.s.l.

Aquattuor stereosathe Enghoff, 2015

Figs 1, 6D-F, 8A, 9

Aquattuor stereosathe Enghoff, in Enghoff \& Frederiksen, 2015: 15.

\section{Diagnosis}

Diameter 1.68-1.75 mm, 46-51 podous rings (Fig. 9). Shares a short (as broad as long, or slightly longer) gonopodal palette with A. claudiahempae, A. denticulatus, A. fasciatus, A. submajor and A. udzungwensis. Differs from these species by having the gonopodal telomere describing a ca $360^{\circ}$ curve, curving in three dimensions, and by having the telomere tip with coarsely laciniate margins and a surface that is not microspiculate.

Material studied (total: 1 ঐ)

TANZANIA $\bullet 1 \hat{\partial}$, paratype; Iringa Region, Udzungwa Mts, Udzungwa Scarp FR, above Chita Village; 1050 m a.s.1.; 26-29 Oct. 1984; N. Scharff leg.; pitfall trap in intermediate rain forest; NHMD 621650.

\section{Descriptive notes}

First pair of male legs (Figs 6D-F): prefemoral processes relatively stout, triangular; setae of telopodite distal to prefemur same length as setae of normal walking legs.

\section{Distribution}

Known only from the Udzungwa Scarp FR in the Udzungwa Mts. Altitudinal range: 900-1500 m a.s.1.

Aquattuor submajor Enghoff, 2015

Figs $1,7 \mathrm{~A}-\mathrm{C}, 9,16,18$

Aquattuor submajor Enghoff, in Enghoff \& Frederiksen, 2015: 7.

\section{Diagnosis}

Diameter 1.41-1.87 mm, 41-48 podous rings (Fig. 9). Shares a short (as broad as long, or slightly longer) gonopodal palette with A. claudiahempae, A. denticulatus, A. fasciatus, A. stereosathe and 
A. udzungwensis. Differs from these species by the combination of fully developed telopodites on the first pair of male legs, the gonopodal telomere describing a ca $270^{\circ}$ curve, curving almost in one plane only, by lacking a spinose lid-like flap on the besal telomeral lamella and by lacking a distinct mesobasal lobe of the gonopod palette.
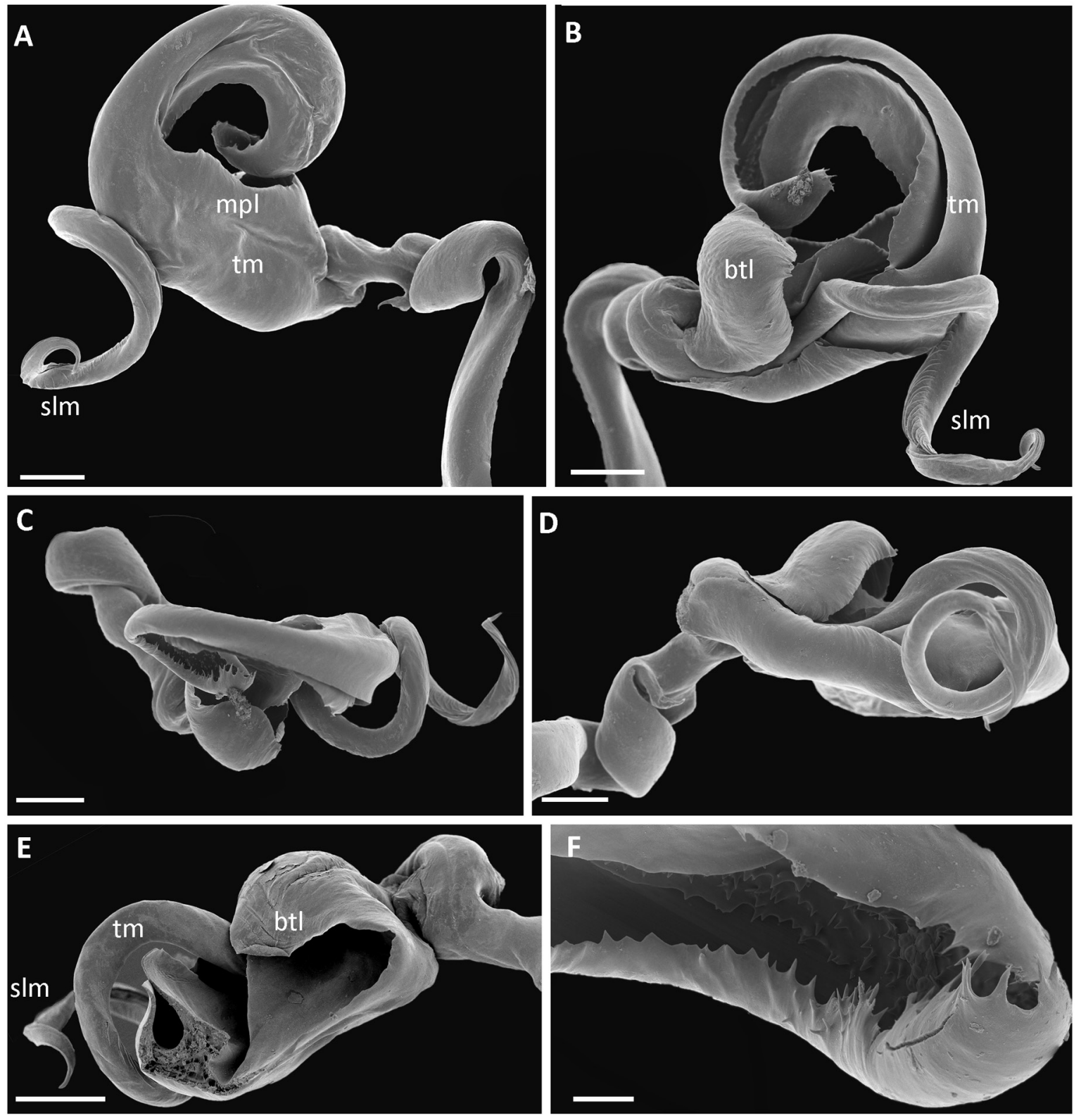

Fig.16. Aquattuor submajor Enghoff, 2015. A-D. Male from Udzungwa Mts National Park, Kidatu (NHMD 621653), left gonopod telopodite. A. Posterior view. B. Anterior view. C. Distal (ventral) view. D. Basal (dorsal) view. E-F. Male from Udzungwa Mts National Park, Kidatu (NHMD 621654), right gonopod telopodite, broken into two pieces. E. Basal part. F. Tip of telomere. Abbreviations: $b t l=$ basal telomeral lamella; $\mathrm{mpl}=$ meso-posterior telomeral lamella; $\mathrm{slm}=$ solenomere; $\mathrm{tm}=$ telomere. Scale bars: $\mathrm{A}-\mathrm{E}=0.1 \mathrm{~mm} ; \mathrm{F}=0.02 \mathrm{~mm}$. 
Table 1. Comparison of Aquattuor submajor Enghoff, 2015 (males) from Mwanihana and Kidatu.

\begin{tabular}{lcc}
\hline & podous rings & midbody vertical diameter (mm) \\
\hline $\begin{array}{l}\text { Mwanihana (1000-1100 m a.s.1.), data } \\
\text { from Enghoff \& Frederiksen (2015) }\end{array}$ & $45-48$ & $1.55-1.87$ \\
$\begin{array}{l}\text { Kidatu (1448-1552 m a.s.l), new } \\
\text { material }\end{array}$ & $41-44$ & $1.41-1.57$ \\
\hline
\end{tabular}

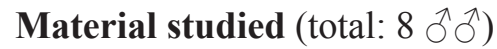

TANZANIA • 1 d , paratype; Udzungwa Mts, Mwanihana Forest above Sanje; 1000 m a.s.1.; 1 Aug. 1981; N. Scharff leg.; pitfall trap; NHMD 261651 • 1 §̊; Morogoro Region, Udzungwa Mts National Park, Kidatu, Plot 5; 0740'45.5" S, 36 55'06.9" E; 1448 m a.s.1.; 21 Oct. 2014; J. Malumbres-Olarte leg.; pitfall trapping; NHMD 621652 1 ô; Morogoro Region, Udzungwa Mts National Park, Kidatu, Plot 6; 07²0'42.1" S, 36 55'06.8" E; 1482 m a.s.l.; 21 Oct. 2014; J. Malumbres-Olarte leg.; pitfall

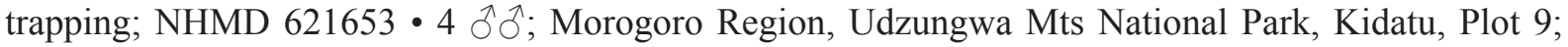
$07^{\circ} 41^{\prime} 06.2^{\prime \prime}$ S, 36 54'52.4" E; 1527 m a.s.1.; 23 Oct. 2014; J. Malumbres-Olarte leg.; pitfall trapping (summed catch from four traps); NHMD 621654 - 1 त; Morogoro Region, Udzungwa Mts National Park, Mito Mitatu, Plot 15; 07²9'39.8" S, 3650'26.9" E; 1552 m a.s.l.; 27 Oct. 2014; J. MalumbresOlarte leg.; pitfall trapping; NHMD 621655.

\section{Descriptive notes}

The newly studied specimens from Kidatu are considerably smaller than those from Mwanihana FR; see Table 1.

First pair of male legs (Figs 7A-C): prefemoral processes finger-shaped; setae of telopodite distal to prefemur same length as setae of normal walking legs.

Gonopod telopodite (Fig. 16): basal telomeral lamella ( $b t l)$ forming a subspherical chamber but without a spinose lid-like flap, cf. A. udzungwensis. In the specimen illustrated in Fig. 16 the tip has remarkably long marginal laciniae, approaching the condition typical of $A$. stereosathe (Enghoff \& Frederiksen 2015: fig. 9c).

\section{Remarks}

The distinction between A. submajor and A. udzungwensis is discussed under the latter species.

\section{Distribution}

Known from Mwanihana FR and Kidatu in Udzungwa Mts National Park. Altitudinal range: 1000-1552 m a.s.1.

Aquattuor udzungwensis Enghoff, 2015

Figs 1, 2, 7D-E, 9, 17-18

Aquattuor udzungwensis Enghoff, in Enghoff \& Frederiksen, 2015: 13. 


\section{Diagnosis}

Diameter 1.44-1.75 mm, 44-54 podous rings (Fig. 9). Shares a short (as broad as long, or slightly longer) gonopodal palette with A. claudiahempae, A. denticulatus, A. fasciatus, A. stereosathe and A. submajor. Differs from these species by having the telopodite of the first pair of male legs represented by the prefemur only, and by having the basal telomeral lamella forming a subspherical chamber with a spinose, lid-like flap.

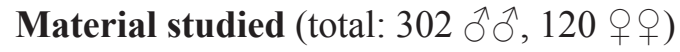

TANZANIA • 4 $\lesssim$, paratypes; Iringa Region, Udzungwa Mts, Udzungwa Scarp FR, above Chita Village; $730 \mathrm{~m}$ a.s.1.; 25-29 Oct. 1984; N. Scharff leg.; pitfall traps in lowland rain forest; NHMD 621656

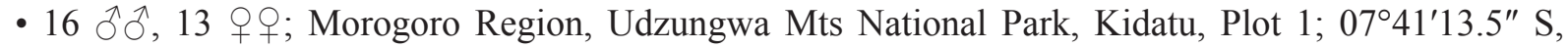
3656'28.6" E; $650 \mathrm{~m}$ a.s.l.; 24 Oct. 2014; J. Malumbres-Olarte leg.; pitfall trapping (summed catch from seven traps); NHMD 621657 • 1 §, 4 우; Morogoro Region, Udzungwa Mts National Park, Kidatu, Plot 2; 07²1'14.9" S, 36 56'24.7" E; 650 m a.s.1.; 24 Oct. 2014; J. Malumbres-Olarte leg.;

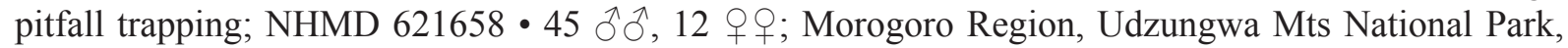
Kidatu, Plot 3; 0741'02.4" S, 3655'49.3" E; 1005 m a.s.l.; 14 Oct. 2014; J. Malumbres-Olarte leg.; pitfall trapping (summed catch from twelve traps); NHMD 621659 • 24 ๙ $\partial^{2}, 2$ 우 ; Morogoro Region, Udzungwa Mts National Park, Kidatu, Plot 4; 07²41'05.2" S, 3655'48.4" E; 993 m a.s.1.; 15 Sep. 2014; J. Malumbres-Olarte leg.; pitfall trapping (summed catch from eight traps); NHMD 621660 • 8 § $\sigma^{\lambda}$, 5 우; Morogoro Region, Udzungwa Mts National Park, Kidatu, Plot 7; 07²41'23.4" S, 36 56 $00.7^{\prime \prime}$ E; $708 \mathrm{~m}$ a.s.1.; 24 Oct. 2014; J. Malumbres-Olarte leg.; pitfall trapping (summed catch from six traps);

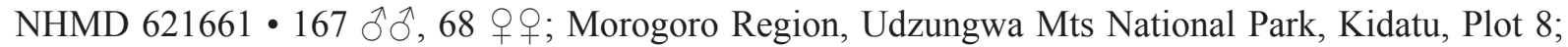
07²1'12.9" S, 36 55'39.2" E; 978 m a.s.1.; 14 Oct.2014; J. Malumbres-Olarte leg.; pitfall trapping

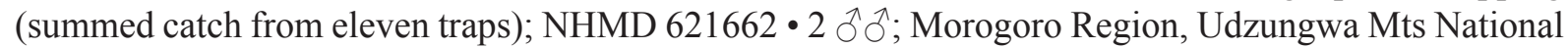
Park, Mito Mitatu, Plot 13; 0750'29.6" S, 36 52'01.3" E; 674 m a.s.1.; 26 Oct. 2014; J. MalumbresOlarte leg.; pitfall trapping (summed catch from two traps); NHMD 621663 5 § $\partial^{\lambda}, 2$ 우; Morogoro Region, Udzungwa Mts National Park, Mito Mitatu, Plot 14; 0750'26.1" S, 3651'33.0" E; 1006 m a.s.l.; 26 Oct. 2014; J. Malumbres-Olarte leg.; pitfall trapping (summed catch from four traps); NHMD 621664 - 1 ơ; Morogoro Region, Udzungwa Mts National Park, Mito Mitatu, Plot MM2; 0750'15.1" S,

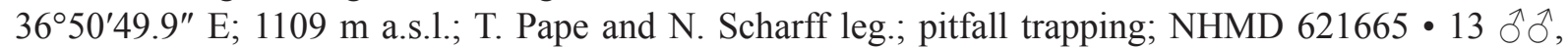
4 우; Morogoro Region, Udzungwa Scarp Catchment Forest Reserve, Chita, Plot 16; 08 30'13.4" S, 35 55'08.9" E; 659 m a.s.l.; 31 Oct. 2014; J. Malumbres-Olarte leg.; pitfall trapping (summed catch

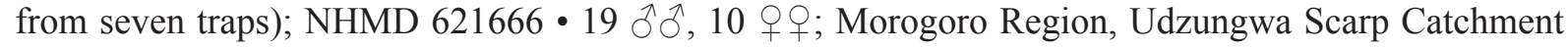
Forest Reserve, Chita, Plot 17; 08²9'58.1" S, 3554'59.5" E; 908 m a.s.1.; 30 Oct. 2014; J. MalumbresOlarte leg.; pitfall trapping (summed catch from six traps); NHMD 621667.

\section{Descriptive notes}

The newly studied specimens on average have more podous rings than those studied by Enghoff \& Frederiksen (2015) (Fig. 9). In particular, the specimens from Kidatu and Mito Mitatu have more podous rings (49-54, most specimens 53), whereas the new specimens from Chita (49-51 podous rings) overlap with the previously studied ones; see also Discussion.

First pair of male legs (Fig. 7D-E): prefemoral processes finger-shaped to triangular; telopodital podomeres distal to prefemur missing in all studied specimens; see Discussion.

Gonopod telopodite (Fig. 17): basal telomeral lamella (btl) forming a subspherical chamber with a spinose, lid-like flap, cf. A. submajor and remarks below. 

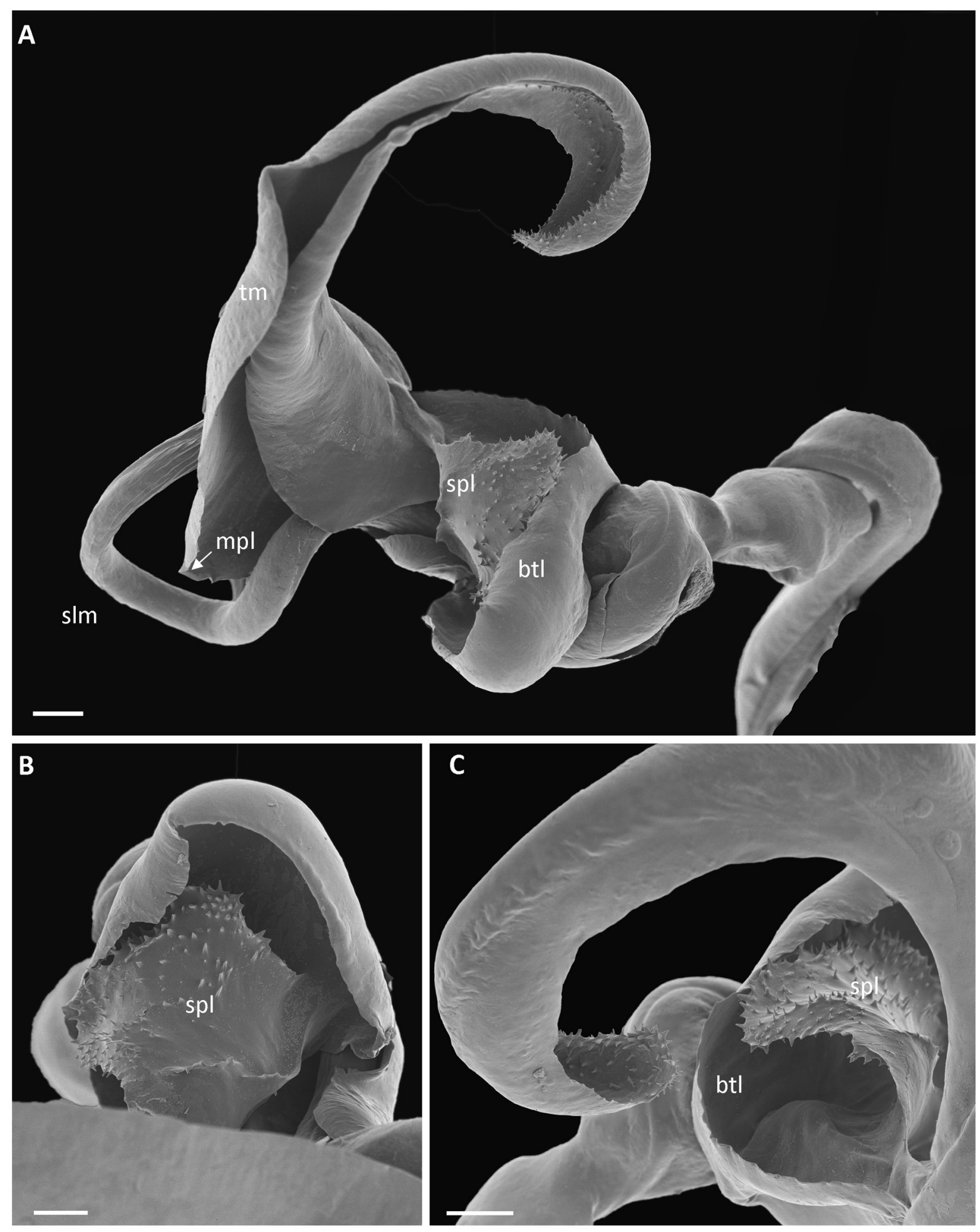

Fig. 17. Aquattuor udzungwensis Enghoff, 2015, male from Udzungwa Mts National Park, Kidatu (NHMD 621659), left gonopod telopodite. A. (Meso-)posterior view. B. Basal telomeral lamella, distal (ventral) view. C. Telomere, sublateral view. Abbreviations: $b t l=$ basal telomeral lamella; $m p l=$ mesoposterior telomeral lamella, the arrow points to the diagnostic angle; $s l m=$ solenomere; $s p l=$ spinose lid-like flap; $t m=$ telomere. Scale bars $=0.05 \mathrm{~mm}$. 


\section{Remarks - The distinction between $A$. submajor and $A$. udzungwensis}

The distinction between A. udzungwensis and A. submajor according to Enghoff \& Frederiksen (2015) is quite subtle. The newly studied material has contributed to a better understanding of the differences between these two species. Among the differences stated by Enghoff \& Frederiksen (2015), the shape of the meso-posterior lamella of the telomere seems to be the only reliable one (Figs 16-17). The mesoposterior lamella is high and basally angled in A. udzungwensis, and towards the tip of the telomere, the lamella narrows gradually. In A. submajor, the lamella is lower, not angled, and not narrowing so strongly towards the tip.

However, two new clear differences can now be added:

- The basal telomeral lamella (btl) in A. udzungwensis has a small, spinose, lid-like flap (spl) (Fig. 17); such a flap is absent in A. submajor (Fig. 16).

- In all dissected males of $A$. udzungwensis (>10), collected in several parts of the Udzungwa Mts, the telopodites of the first leg-pair are strongly reduced distal to the prefemur (Fig. 7D-E). Only tiny, somewhat irregular and darkened remnants are present, suggesting that their absence may be due to some physical damage inflicted on the male. In all examined males of $A$. submajor, the telopodites are normal (Fig. 7A-C).

For both species, the newly studied material considerably widens their size range: newly studied specimens of $A$. submajor have fewer podous rings and a smaller body diameter than those studied by Enghoff \& Frederiksen (2015); in A. udzungwensis the newly studied specimens tend to have more podous rings than those previously studied, while there is a marked difference in diameter. These differences may, at least in part, be correlated with altitude: both species show a clear decrease of numbers of podous rings with increasing altitude from mostly $>50$ podous rings at $600-900 \mathrm{~m}$ altitude to $<46$ rings at $1400-1550 \mathrm{~m}$ altitude (Fig. 18).

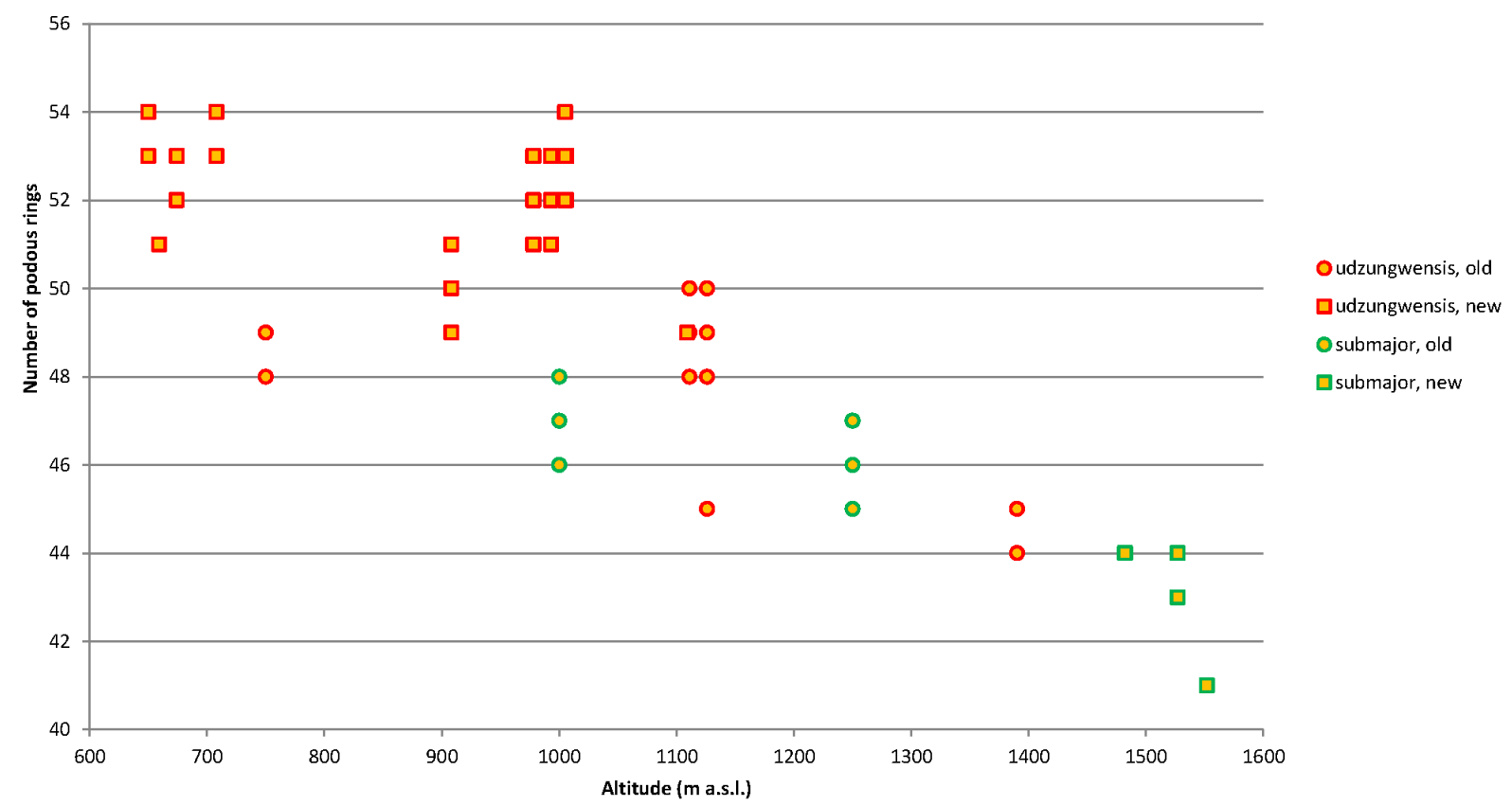

Fig. 18. Aquattuor submajor Enghoff, 2015 and A. udzungwensis Enghoff, 2015; numbers of podous rings as a function of altitude. 


\section{Distribution}

Known from several localities in the Udzungwa Mts (Fig. 1). Altitudinal range: 650-1410 m a.s.1.

\section{Aquattuor sp.}

\section{Material studied}

TANZANIA - Several $+q$ /juveniles; Morogoro, Sokoine University Campus, NORAD guest house; 28 Mar. 1989; Zicsi leg.; HMNH.

\section{Remarks}

These specimens represent a range extension of the genus Aquattuor, but a closer identification is not possible.

\section{Key to the species of Aquattuor (males)}

1. Palette ( $p a)$ of gonopods elongate, considerably to much longer than broad (Figs 11-12; Enghoff \& Frederiksen 2015: figs 6-7); first pair of legs with a distal prefemoral lobe (Figs 5, 6A-C); 48+ podous rings, diameter $>1.7 \mathrm{~mm}$

- Palette as long as broad or slightly longer; first pair of legs without a distal prefemoral lobe (as in Fig. 3); diameter $<1.9 \mathrm{~mm}$

2. Palette ( $p a)$ not clearly delimited by lateral (li) and mesal ( $m i$ incisions (Fig. 12A); tarsal setae of first pair of legs much shorter than tarsal setae of normal walking legs (Fig. 8C)

A. mollilobus sp. nov. (Udzungwa)

- Palette delimited by lateral and mesal incisions (e.g., Fig. 11A); tarsal setae of first pair of legs ca of same length as tarsal setae of normal walking legs (Fig. 8B)

3. 53-54 podous rings, diameter $>1.9 \mathrm{~mm}$; anterior margin of telomere with a triangular tooth (Enghoff \& Frederiksen 2015: fig. 6A, $t$ )

A. major Enghoff, 2015 (Udzungwa)

- 50-52 podous rings; anterior margin of telomere without a triangular tooth

A. longipala Enghoff, 2015 (Udzungwa)

4. Subdistal part of telomere almost straight, parallel to coxa; telomere tip bent abruptly laterad (Enghoff \& Frederiksen 2015: fig. 11); 50-52 podous rings, diameter 1.6-1.8 mm

A. denticulatus Frederiksen, 2013 (E Usambara)

- Telomere describing a more complex curve

5. Gonopod coxa without lateral and mesal incisions; telomere tip flattened, smooth (Figs 14-15) ..... A. nguruensis sp. nov. (Nguru)

- Gonopod coxa with lateral $(\mathrm{li})$ and mesal $(\mathrm{mi})$ incisions; telomere tip microspiculate or with serrated margins

6. Telomere describing a ca $360^{\circ}$ curve, curving in three dimensions; telomere tip with coarsely laciniate margins, but surface not microspiculate (Enghoff \& Frederiksen 2015: fig. 9)

A. stereosathe Enghoff, 2015 (Udzungwa)

- Telomere describing a ca $270^{\circ}$ curve, curving almost in one plane only; telomere tip more or less microspiculate 
7. Telopodites of first pair of legs only represented by prefemur; basal telomeral lamella $(b t l)$ forming a subspherical chamber with a spinose, lid-like flap (Fig. 17)

A. udzungwensis Enghoff, 2015 (Udzungwa)

- Telopodites of first pair of legs fully developed; basal telomeral lamella without a spinose, lid-like flap

8. < 49 podous rings; meso-basal lobe of gonopod palette indistinct (Enghoff \& Frederiksen 2015: fig. 5).

- $>48$ podous rings; meso-basal lobe $(\mathrm{mbl}$ ) of gonopod palette well-developed (Enghoff \& Frederiksen 2015: fig. 10; Enghoff 2016: fig. 7)

9. Diameter $>1.5 \mathrm{~mm}$. Prefemoral processes of first pair of legs subtriangular (Fig. 3A-C)

A. fasciatus (Attems, 1896) (Zanzibar, Rubeho Mts, Mt Vula)

- Diameter $<1.7 \mathrm{~mm}$. Prefemoral processes of first pair of legs finger-shaped (Fig. 3D-I)

A. claudiahempae Enghoff \& Frederiksen, 2015 (Udzungwa, Kilimanjaro)

\section{Discussion}

\section{Intrageneric relationships}

A preliminary study of relationships between eight Aquattuor species (A. denticulatus and A. mollilobus sp. nov. were not included), based on the CO1 gene and partly on the $16 \mathrm{~S}$ gene, was made by Sara Frederiksen. The results indicate a close relationship between, and a short genetic distance between each of the pairs A. major/longipala, A. claudiahempae/fasciatus and A. udzungwensis (West Kilombero Scarp FR)/udzungwensis (Udzungwa Scarp FR), but are otherwise inconclusive. These findings seem to agree with morphological evidence: A. major and A. longipala, together with $A$. mollilobus sp. nov. share an elongate gonocoxal palette, a distal prefemoral lobe and shortened telopodital setae of the first pair of legs; A. claudiahempae and A. fasciatus are extremely similar, and their separate species status may even be questioned.

\section{Distribution patterns}

Out of the ten currently known species of Aquattuor, seven occur, six of them as endemics, in the Udzungwa Mts, which thus is clearly a 'center of diversity' for this genus. The seventh Udzungwa species, A. claudiahempae, is also known from disturbed habitats on Mt Kilimanjaro. Two species, A. denticulatus and A.nguruensis sp. nov., are endemic to the East Usambara and Nguru Mts, respectively, and the tenth species, A. fasciatus, is known from coastal Tanzania and the Rubeho Mts.

Within the Udzungwa Mts there is a strong concentration of species in the NE part (Udzungwa Mts National Park, the former Mwanihana FR, see Fig. 1). Aquattuor major, A. mollilobus sp. nov. and A. submajor are known only from this area; A. longipala is also known from the former West Kilombero FR further west, and $A$. udzungwensis is widespread in the Udzungwas from NE to SW. The SW of the Udzungwas (Udzungwa Scarp FR) harbor one endemic species, A. stereosathe.

In the absence of a phylogenetic hypothesis little can be said about this distribution pattern. It may, however, be noticed that the one species shared between the Udzungwas and elsewhere, viz., A. claudiahempae, in the Udzungwas has been collected only at a relatively low altitude (650 $\mathrm{m}$ a.s.1.). This is in agreement with the altitudinal pattern of Udzungwa odontopygids found by Enghoff (2018a), viz., that the few non-endemic Udzungwas, except one, have been collected at the lowest-lying sites. On Mt Kilimanjaro, A. claudiahempae occurs in disturbed habitats, and accidental transport by humans may well have played a role is the dispersal of this species, as may also be the case with A. fasciatus (the status of this species vis-à-vis $A$. claudiahempae is even dubious). 


\section{Altitudinal differences in ring numbers}

Two species known from several sites in the Udzungwa Mts, viz., A. submajor and A. udzungwensis, show a negative correlation between altitude and numbers of podous rings (Fig. 18). Such a decrease is, however, not a general trend in millipedes. Thus, in the European Ommatoiulus sabulosus (Linnaeus, 1758) (Julida: Julidae), according to studies by F. Sahli synthesized by Enghoff et al. (1993), specimens of a high-altitude population grew to having more podous rings than those in a low-altitude population.

\section{The first pair of male legs}

As mentioned in the introduction, the first pair of odontopygid male legs has not been described systematically in the literature. Published drawings, e.g., Attems (1909: fig. 51; 1953: fig. 180), Brolemann (1920: fig. xxx), Hoffman \& Howell (1981: fig. 2) and Schubart (1966: figs 105, 108, 113, $117,121,126,132)$ do suggest some differences between taxa, and the present study confirms that the first pair of legs should receive more attention.

Within Aquattuor alone, the shape of the prefemoral processes varies (finger-shaped or triangular, straight or curved); an additional distal prefemoral lobe may be present or absent; the setae of the telopodite may be reduced in length to varying degrees, the telopodital podomeres distal to the prefemur may be absent. The last-mentioned condition is puzzling. In all examined males of $A$. udzungwensis, the telopodite seems to have been broken off between prefemur and femur, rather than not having been formed from the beginning. Such damage may have been inflicted during copulation, in analogy with the situation in Julus scandinavius Latzel, 1884 (Julida: Julidae) where males are very often found with the long coxal processes of the second pair of legs broken (Schubart 1934; pers. obs.) - during mating, females 'lick' an attractive substance from these processes (Haacker 1969), and while doing so may break them. In Spirostreptidae, the first pair of legs plays a role in the 'fixation' of the female during copulation (Krabbe 1982); there is no reason to believe that this is different in their close relatives the odontopygids, and the lack of the distal telopodital podomeres in A. udzungwensis might be due to ?accidental bites from the females.

\section{Acknowledgements}

Thanks are due to Tanzania National Parks (TANAPA), the Tanzania Commission for Science and Technology (COSTECH) and the Tanzania Wildlife Research Institute (TAWIRI) for permits allowing field work in the Udzungwa Mts. Thanks are also due to Jagoba Malumbres-Olarte for collecting very large samples of Aquattuor spp., to Kal Ivanov (VMNH) and Laszlo Dányi (HMNH) for lending important specimens, to Sara Frederiksen for making the preliminary phylogenetic analysis, to Luiz Iniesta for instructions in some of Photoshop's more advanced functions and to the Eastern Arc Mountains Conservation Endowment Fund for permission to use the inset map in Fig. 1. Nesrine Akkari, Dragan Antić and Boyan Vagalinski are thanked for very helpful suggestions for improving the manuscript.

\section{References}

Attems C.G. 1896. Beschreibung der von Dr. Stuhlmann in Ost-Afrika gesammelten Myriopoden. Jahrbuch der hamburgischen wissenschaftlichen Anstalten 13, Suppl.: 23-42.

Available from: https://biodiversitylibrary.org/page/28745426 [accessed 1 Oct. 2019].

Attems C. 1909. Myriopoda. In: Sjöstedt Y. (ed.) Wissenschaftliche Ergebnisse der schwedischen zoologischen Expedition nach dem Kilimandjaro, dem Meru und den umgebenden Massaisteppen Deutsch-Ostafrikas 1905-1906, unter Leitung von Prof. Dr. Yngve Sjöstedt 3 (19): 1-64. Available from: https://biodiversitylibrary.org/page/1410223 [accessed 1 Oct. 2019].

Attems C.G. 1914. Afrikanisiche Spirostreptiden nebst Überblick über die Spirostreptiden orbis terrarum. Zoologica Stuttgart 65-66: 1-233. 
Attems C. 1953. Neue Myriopoden des belgischen Congo. Annales du Musée royal du Congo Belge, Série 8o, Sciences Zoologiques 18: 1-139.

Brolemann H.W. 1920. Myriapodes. In: Allaud Ch. (ed.) Voyage de Ch. Alluaud et R. Jeannel en Afrique Orientale 1911-1912. Résultats Scientifiques, Myriapoda 3: 49-298. A. Schultz, Paris.

Enghoff H. 2014. A mountain of millipedes I: An endemic species-group of the genus Chaleponcus Attems, 1914, from the Udzungwa Mountains, Tanzania (Diplopoda, Spirostreptida, Odontopygidae). European Journal of Taxonomy 100: 1-75. https://doi.org/10.5852/ejt.2014.100

Enghoff H. 2016a. A mountain of millipedes III: A new genus for three new species from the Udzungwa Mountains and surroundings, Tanzania, as well as several 'orphaned' species previously assigned to Odontopyge Brandt, 1841 (Diplopoda, Spirostreptida, Odontopygidae). European Journal of Taxonomy 177: 1-19. https://doi.org/10.5852/ejt.2016.177

Enghoff H. 2016b. A mountain of millipedes IV: Species of Prionopetalum Attems, 1909, from the Udzungwa Mountains, Tanzania. With notes on "P." fasciatum (Attems, 1896) and a revised species key (Diplopoda, Spirostreptida, Odontopygidae). European Journal of Taxonomy 215: 1-23.

https://doi.org/10.5852/ejt.2016.215

Enghoff H. 2016c. A mountain of millipedes V: Three new genera of Odontopygidae from the Udzungwa Mountains, Tanzania. (Diplopoda, Spirostreptida, Odontopygidae). European Journal of Taxonomy 221: 1-17. https://doi.org/10.5852/ejt.2016.221

Enghoff H. 2018a. A mountain of millipedes VI. New records, new species, a new genus, and a general discussion of Odontopygidae from the Udzungwa Mts, Tanzania (Diplopoda, Spirostreptida, Odontopygidae). European Journal of Taxonomy 394: 1-29. https://doi.org/10.5852/ejt.2018.394

Enghoff H. 2018b. A mountain of millipedes VII. The genus Eviulisoma Silvestri, 1910, in the Udzungwa Mountains, Tanzania, and related species from other Eastern Arc mountains. With notes on Eoseviulisoma Brolemann, 1920, and Suohelisoma Hoffman, 1963 (Diplopoda, Polydesmida, Paradoxosomatidae). European Journal of Taxonomy 445: 1-90. https://doi.org/10.5852/ejt.2018.445

Enghoff H. \& Frederiksen S.B. 2015. A mountain of millipedes II: The genus Aquattuor Frederiksen, 2013 - five new species from the Udzungwa Mountains and one from Mt. Kilimanjaro, Tanzania (Diplopoda, Spirostreptida, Odontopygidae). European Journal of Taxonomy 150: 1-25. https://doi.org/10.5852/ejt.2015.150

Enghoff H., Dohle W. \& Blower J.G. 1993. Anamorphosis in millipedes (Diplopoda) - the present state of knowledge with some developmental and phylogenetic considerations. Zoological Journal of the Linnean Society 109: 103-234. https://doi.org/10.1111/j.1096-3642.1993.tb00305.x

Enghoff H., Hoffman R.L. \& Howell K.M. 2016. Checklist of the millipedes (Diplopoda) of Tanzania. Journal of East African Natural History 105 (1): 51-113. https://doi.org/10.2982/028.105.0103

Frederiksen S.B. 2013. East African odontopygid millipedes 3: Two new genera, Lamelloramus and Aquattuor proposed to contain three new species (Diplopoda, Spirostreptida, Odontopygidae). Zootaxa 3694: 59-66. https://doi.org/10.11646/zootaxa.3694.1.4

Haacker U. 1969. An attractive secretion in the mating behaviour of a millipede. Zeitschrift für Tierpsychologie 26: 988-990. https://doi.org/10.1111/j.1439-0310.1969.tb01986.x

Hoffman R.L. \& Howell K.M. 1981. A new genus, composed of brightly colored East African species, in the diplopod family Odontopygidae. Revue de Zoologie africaine 95 (3): 687-696.

Krabbe E. 1979. The first pair of legs in male Spirostreptidae: their function and taxonomic importance. In: Camatini M. (ed.) Myriapod Biology: 59-72. Academic Press. London. 
Krabbe E. 1982. Systematik der Spirostreptidae (Diplopoda, Spirostreptomorpha). Abhandlungen des naturwissenschaftlichen Vereins in Hamburg (NF) 24: 1-476.

Kraus O. 1960. Äthiopische Diplopoden I. Monographie der Odontopygidae-Odontopyginae (Diplopoda, Spirostreptoidea). Annalen van het Koninklijk Museum van Belgisch-Congo 82: 1-207.

Marshall A.R., Jørgensbye H.I.O., Rovero F., Platts P.L., White P.C.L. \& Lovett J.C. 2010. The speciesarea relationship and confounding variables in a threatened monkey community. American Journal of Primatology 72: 325-336. https://doi.org/10.1002/ajp.20787

Mauriès J.-P. 1997. Is the family Atopogestidae based on a case of teratology or a periodomorphic stage? (Diplopoda, Spirostreptida: Odontopygoidea). Entomologica Scandinavica Supplement 51: 139-147.

Schubart O. 1934. Tausendfüssler oder Myriapoda I: Diplopoda. Die Tierwelt Deutschlands 28: i-vii + $1-318$.

Schubart O. 1966. Diplopoda III. Pselaphognatha, Opisthospermophora, Colobognatha. South African Animal Life 12: 9-227.

VandenSpiegel D. \& Pierrard G. 2009. Révision du genre Prionopetalum (Odontopygidae, Diplopoda) et descriptions de nouvelles espèces d'Afrique de l'Est. Journal of Afrotropical Zoology 5: 149-163.

Manuscript received: 18 October 2019

Manuscript accepted: 6 January 2020

Published on: 14 April 2020

Topic editor: Rudy Jocqué

Topic editor: Nesrine Akari

Desk editor: Pepe Fernández

Printed versions of all papers are also deposited in the libraries of the institutes that are members of the EJT consortium: Muséum national d'histoire naturelle, Paris, France; Meise Botanic Garden, Belgium; Royal Museum for Central Africa, Tervuren, Belgium; Royal Belgian Institute of Natural Sciences, Brussels, Belgium; Natural History Museum of Denmark, Copenhagen, Denmark; Naturalis Biodiversity Center, Leiden, the Netherlands; Museo Nacional de Ciencias Naturales-CSIC, Madrid, Spain; Real Jardín Botánico de Madrid CSIC, Spain; Zoological Research Museum Alexander Koenig, Bonn, Germany; National Museum, Prague, Czech Republic. 